\section{Special Report 88-14}

September 1988

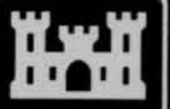

US Army Corps of Engineers

Cold Regions Research \& Engineering Laboratory

\title{
Eruptions from under-ice explosions
}

\author{
Malcolm Mellor and David L'Heureux
}




\section{REPORT DOCUMENTATION PAGE}

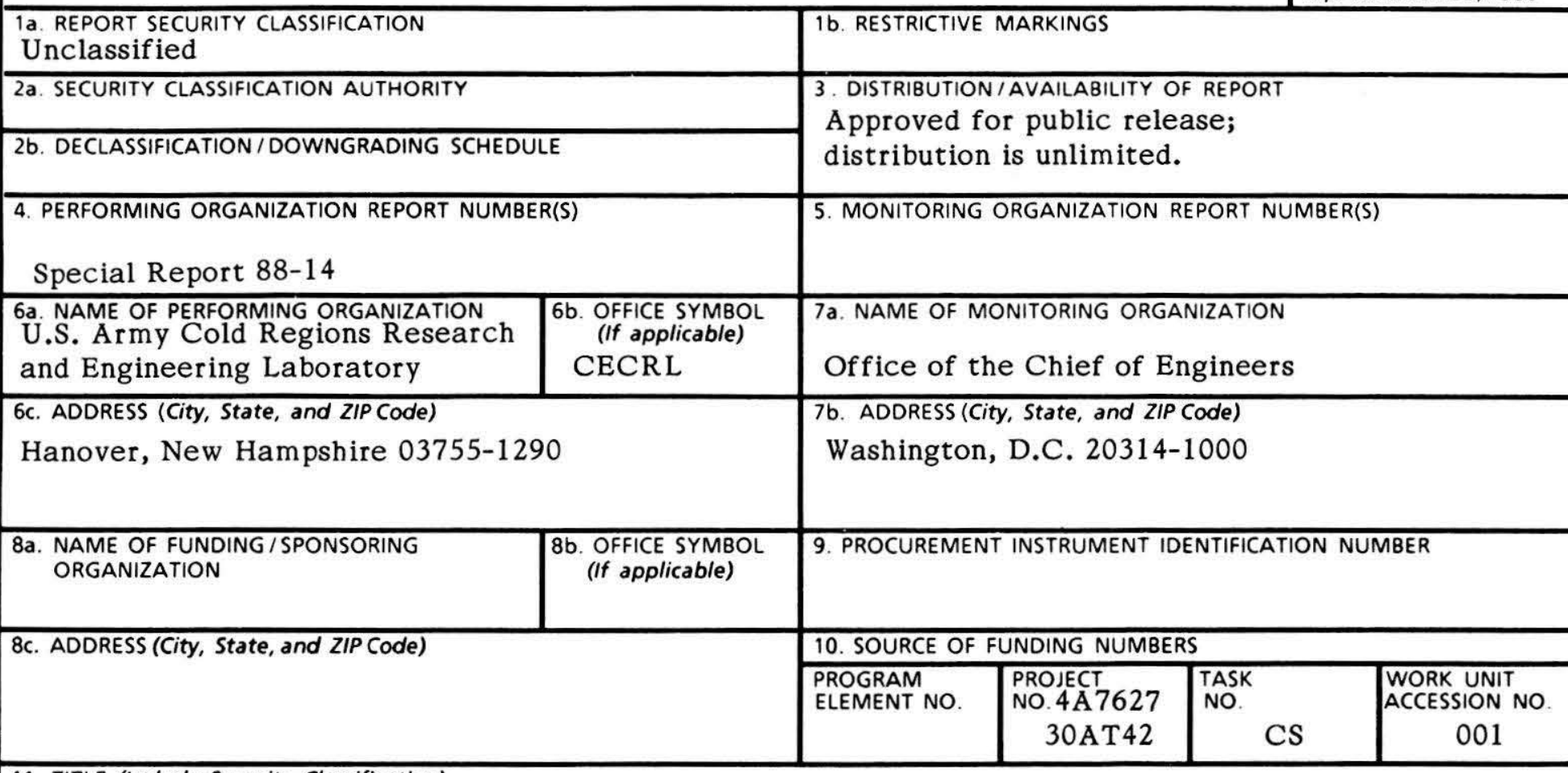

11. TITLE (Include Security Classification)

Eruptions from Under-Ice Explosions

12. PERSONAL AUTHOR(S)

Mellor, Malcclm and L'Heureux, David

\begin{tabular}{|l|l|l|l|l}
\hline 13a. TYPE OF REPORT & 13b. TIME COVERED & 14. DATE OF REPORT (Year, Month, Day) & 15. PAGE COUNT
\end{tabular}

16. SUPPLEMENTARY NOTATION FROM TO TO September 1988 28

17

\begin{tabular}{|l|l|l|}
\hline 17. & \multicolumn{3}{|c|}{ COSATI CODES } \\
\hline FIELD & GROUP & SUB-GROUP \\
\hline & & \\
\hline & & \\
\hline
\end{tabular}

18. SUBJECT TERMS (Continue on reverse if necessary and identify by block number) Eruptions Ice penetration Explosions Under-ice explosions Explosives Underwater explosions

19. ABSTRACT (Continue on reverse if necessary and identify by block number)

Eruptions from under-ice explosions were recorded by a standard video camera and an ordinary motordriven 35-mm camera. The records give the dimensions and velocities of the eruptions. Velocity, diameter, and height are related to charge depth and the results are compared with data for ordinary underwater explosions in ice-free water.

\begin{tabular}{l} 
20. DISTRIBUTION / AVAILABILITY OF ABSTRACT \\
UNCLASSIFIED/UNLIMITED $\square$ SAME AS RPT. $\square$ DTIC USERS \\
\hline 22a. NAME OF RESPONSIBLE INDIVIDUAL \\
MalCOlm Mellor
\end{tabular}

83 APR edition may be used until exhausted. All other editions are obsolete
21. ABSTRACT SECURITY CLASSIFICATION Unclassified

22b. TELEPHONE (Include Area Code) 22 c. OFFICE SYMBOL
603-646-4100 


\section{PREFACE}

This report was prepared by Dr. Malcolm Mellor, Experimental Engineering Division, and David L'Heureux, Visual Information Branch, Information Management Division, U.S. Army Cold Regions Research and Engineering Laboratory.

Field data for this report were gathered during a winter bridging exercise with Echo Company, 2nd Engineer Battalion, in Korea. The field project was carried out under DA Project 4A762730AT42, Design, Construction, and Operations Technology for Cold Regions, Task CS, Bridging Concepts, Work Unit 001, Cold Weather Bridging. The report was prepared under the same project, Task CS, Vehicular Barriers, Work Unit 029, Explosives and Projectile Impact Under Winter Conditions.

The contents of this report are not to be used for advertising or promotional purposes. Citation of brand names does not constitute an official endorsement or approval of the use of such commercial products. 


\title{
Eruptions from Under-Ice Explosions
}

\author{
MALCOLM MELLOR AND DAVID L'HEUREUX
}

\section{INTRODUCTION}

During a winter bridging study in Korea, underwater explosions were fired beneath a thin ice cover on the Imjin River. The resulting eruptions of water and ice fragments were recorded with a video camera and motor-driven $35-\mathrm{mm}$ cameras. The video tapes and the photographs were used to measure the maximum diameter and height of each eruption, as well as the vertical velocity of the eruption.

The explosions were tests designed to establish procedures for ice-clearing, and consequently they were not ideal for studying the characteristics of the eruptions. However, they did provide some useful information in an area where data are lacking. The records and measurements also demonstrated that simple equipment, used as opportunity offers, is capable of producing good data.

Because the ice thickness was small relative to the size of the charges, these explosions in the Imjin River probably gave eruptions that are not much different from those produced by explosions beneath a free water surface.

\section{TEST EXPLOSIONS}

The primary objective of the work was to develop efficient blasting procedures for clearing a channel across an ice-covered river. Thus most of the tests involved multiple charges, with horizontal separation near the minimum for production of separate eruptions. The ice cover on the river was thin ( $<9$ in., or $<220 \mathrm{~mm}$ ) and the individual charges were relatively large $(5-40 \mathrm{lb}$, or $2.3-18$ $\mathrm{kg}$ ) to minimize the number required, and hence to simplify the blasting procedure. Current velocity in the river was very low, so that the charges hung vertically beneath the ice when inserted through drill holes. The river was quite shallow during the test period, so that scaled charge depths were necessarily limited, and charges sometimes rested on the river bed.
Each charge was inserted through a drill hole or through a hole cut with a chain saw. It was suspended at the required depth on a downline of detonating cord. The detonating cord was initiated on the ice surface by an electric blasting cap. Details of the explosions are given in Table 1, which also lists the size of the crater* that was blown through the ice surface by each explosion. A selection of time-sequence photographs is provided in Appendix A.

\section{DATA FROM THE VIDEO CAMERA}

The video camera was a Panasonic industrial camera, model 3250 , with a Newvicon tube. The recording deck was a Panasonic portable video cassette recorder, model no. NV8429, using the VHS (half-inch tape) system. This was the standard equipment used for recording the general project operations.

The camera was aimed at the charge location and the lens was adjusted to give optimum coverage for the estimated height of the eruption. The camera had to be far enough back to avoid damage from flying debris. Wherever possible, the field of view was chosen to give a dark background (steep, wooded slopes of the riverbank), with any direct sunlight coming from behind the camera. A length scale was provided by laying out a line through the shot point and at right angles to the sight line; the ends of the measured line were marked by dark rocks laid on the ice.

Video taping started prior to the countdown for the blast and continued until after all the debris had finished falling. Tapes were reviewed immediately after each blast in order to make a qualitative assessment of the blast results.

Back in the laboratory, the tapes were run through an editor frame by frame. The height of

\footnotetext{
* Crater-the zone where the ice is fragmented and displaced, leaving open water or fragments that are not connected to the surrounding ice.
} 
Table 1. Results of blasting tests on the Imjin River, 1987.

\begin{tabular}{|c|c|c|c|c|}
\hline $\begin{array}{l}\text { Shot } \\
\text { no. }\end{array}$ & $\begin{array}{l}\text { Ice } \\
\text { thickness } \\
\text { (in.) }\end{array}$ & $\begin{array}{l}\text { Water } \\
\text { depth } \\
\text { (ft) }\end{array}$ & Charge design & Blast effects \\
\hline 1 & 7 & 9 & $\begin{array}{l}3 \times 5-\mathrm{lb} \text { charges of } \mathrm{C}-4 \text { at } 18 \text { - } \mathrm{ft} \text { ctrs. } \\
\text { Outer charges } 2 \mathrm{ft} \text { below top of ice. } \\
\text { Middle charge } 3.3 \mathrm{ft} \text { below top of } \\
\text { ice. No delays. }\end{array}$ & $\begin{array}{l}\text { Crater length } 61 \mathrm{ft} \text {. } \\
\text { Crater width } 28-29 \mathrm{ft} \\
\text { (mean width } 28.5 \mathrm{ft} \text { ). }\end{array}$ \\
\hline 2 & 8 & 6.8 & $\begin{array}{l}3 \times 5-\mathrm{lb} \text { charges of } \mathrm{C}-4 \text { at } 18 \text {-ft ctrs. } \\
\text { Outer charges } 5.6 \mathrm{ft} \text { below top of } \\
\text { ice. Middle charge } 6.8 \mathrm{ft} \text { below top } \\
\text { of ice (on river bed). No delays. }\end{array}$ & $\begin{array}{l}\text { Crater length } 65.5 \mathrm{ft} \text {. } \\
\text { Crater width } 32.5-36.5 \mathrm{ft} \\
\text { (mean width } 34.3 \mathrm{ft} \text { ). }\end{array}$ \\
\hline 3 & 8 & 7 & $\begin{array}{l}3 \times 5-1 b \text { charges of } \mathrm{C}-4 \text { at } 18-\mathrm{ft} \text { ctrs. } \\
\text { All charges } 11.5 \text { in. below top of ice } \\
(3.5 \text { in. below base of ice). } \\
\text { No delays. }\end{array}$ & $\begin{array}{l}\text { Crater length } 65.5 \mathrm{ft} \text {. } \\
\text { Crater width } 38.5-41 \mathrm{ft} \\
\text { (mean width } 39.7 \mathrm{ft} \text { ). }\end{array}$ \\
\hline 4 & 8 & 9.9 & $\begin{array}{l}40 \text {-lb charge of TNT, } 7 \mathrm{ft} \text { below top } \\
\text { of ice. }\end{array}$ & $\begin{array}{l}\text { Crater diameter } 58.3- \\
59.3 \mathrm{ft} \text { (mean } 58.8 \mathrm{ft} \text { ). }\end{array}$ \\
\hline 5 & 8.5 & - & $\begin{array}{l}12 \times 5 \text {-lb charges, } 3 \text { rows, } 20 \mathrm{ft} \text { be- } \\
\text { tween rows, } 20 \mathrm{ft} \text { between charges } \\
\text { in each row. All charges } 2 \mathrm{ft} \text { below } \\
\text { top of ice. Delays between rows. } \\
\text { Zero for left row, } 100 \mathrm{~ms} \text { for center } \\
\text { row, } 200 \mathrm{~ms} \text { for right row (see } \\
\text { diagram). }\end{array}$ & $\begin{array}{l}\text { Crater length } 109 \mathrm{ft} \text {. } \\
\text { Crater width } 83 \mathrm{ft} \text {. }\end{array}$ \\
\hline 6 & 8.5 & - & $\begin{array}{l}12 \times 5 \text {-lb charges of TNT, } 3 \text { rows, } \\
20 \mathrm{ft} \text { between rows, } 20 \mathrm{ft} \text { between } \\
\text { charges in each row. All charges } 2 \mathrm{ft} \\
\text { below top of ice. Delays between } \\
\text { rows. Zero for outer rows, } 200 \mathrm{~ms} \\
\text { for middle row (see diagram). }\end{array}$ & $\begin{array}{l}\text { Crater length } 97 \mathrm{ft} \text {. } \\
\text { Crater width } 77 \mathrm{ft} .\end{array}$ \\
\hline 7 & $8-8.5$ & - & $\begin{array}{l}5 \times 40 \text {-lb charges of TNT. Single } \\
\text { row with charges at } 40-\mathrm{ft} \text { ctrs, } 7 \mathrm{ft} \\
\text { deep. }\end{array}$ & $\begin{array}{l}\text { Crater width } 56 \mathrm{ft} \text { fully } \\
\text { fragmented, } 98 \mathrm{ft} \text { well } \\
\text { fractured with floes } \leq 3 \\
\mathrm{ft} \text {. }\end{array}$ \\
\hline 8 & 7.5 & - & $\begin{array}{l}\text { 40-lb charge of TNT and dynamite. } \\
5 \mathrm{ft} \text { below top of ice. }\end{array}$ & \\
\hline
\end{tabular}

Table 2. Velocity measurements from video records.

\begin{tabular}{|c|c|c|c|c|c|c|c|c|c|}
\hline \multirow[b]{2}{*}{$\begin{array}{c}\text { Shot } \\
\text { no. }\end{array}$} & \multicolumn{2}{|c|}{ Initial velocity } & \multicolumn{2}{|c|}{ Second-stage velocity } & \multirow[b]{2}{*}{$\begin{array}{c}\text { Shot } \\
\text { no. }\end{array}$} & \multicolumn{2}{|c|}{ Initial velocity } & \multicolumn{2}{|c|}{ Second-stage velocity } \\
\hline & $\begin{array}{c}\text { Velocity } \\
\text { (ft/s) }\end{array}$ & $\begin{array}{c}\text { Height } \\
\text { range } \\
\text { (ft) }\end{array}$ & $\begin{array}{c}\text { Velocity } \\
(\mathrm{ft} / \mathrm{s})\end{array}$ & $\begin{array}{c}\text { Height } \\
\text { range } \\
\text { (ft) }\end{array}$ & & $\begin{array}{c}\text { Velocity } \\
\text { (ft/s) }\end{array}$ & $\begin{array}{c}\text { Height } \\
\text { range } \\
\text { (ft) }\end{array}$ & $\begin{array}{c}\text { Velocity } \\
\text { (ft/s) }\end{array}$ & $\begin{array}{c}\text { Height } \\
\text { range } \\
\text { (ft) } \\
\end{array}$ \\
\hline 1 left & 215 & $<57$ & - & - & 5 left & 260 & $<40$ & 193 & $43-75$ \\
\hline 1 right & 232 & $<58$ & - & - & 4 right & 274 & $<40$ & 173 & $48-76$ \\
\hline 1 middle & 161 & $<54$ & - & - & 5 middle & 272 & $<55$ & 194 & $55-74$ \\
\hline 2 left & 108 & $<14$ & 44 & $15-30$ & 6 left & 268 & $<100$ & 218 & $108-145$ \\
\hline 2 right & 103 & $<16$ & 50 & $17-35$ & 6 right & 272 & $<63$ & 179 & 63-134 \\
\hline 2 middle & 162 & $<15$ & 29 & $18-30$ & 6 middle & 299 & $<90$ & 225 & $90-119$ \\
\hline 3 left & 516 & $<32$ & 116 & $32-56$ & 7 left outer & 159 & $<31$ & 100 & $32-78$ \\
\hline 3 right & 562 & - & 121 & $17-42$ & 7 left inner & 154 & $<36$ & 136 & $36-99$ \\
\hline 3 middle & 556 & $<36$ & 100 & $36-62$ & 7 middle & 184 & $<40$ & 113 & $40-93$ \\
\hline & & & & & 7 right inner & 177 & $<42$ & 138 & $44-86$ \\
\hline 4 & 101 & 25 & 85 & $\approx 40$ & 7 right outer & 152 & $<42$ & 114 & $42-70$ \\
\hline
\end{tabular}


Table 3. Measurements made from photographs.

\begin{tabular}{|c|c|c|c|c|c|c|c|c|c|}
\hline \multirow{3}{*}{$\begin{array}{c}\text { Shot } \\
\text { no. }\end{array}$} & \multirow{3}{*}{$\begin{array}{l}\text { Scaled ice } \\
\text { thickness } \\
\left(f t / l b^{1 / 3}\right)\end{array}$} & \multirow{3}{*}{$\begin{array}{c}\text { Scaled } \\
\text { charge } \\
\text { depth } \\
\left(f t / l b^{1 / 3}\right)\end{array}$} & \multirow{2}{*}{\multicolumn{3}{|c|}{$\begin{array}{l}\text { Max. diameter of } \\
\text { column or plume }\end{array}$}} & \multirow{2}{*}{\multicolumn{2}{|c|}{$\begin{array}{l}\text { Max. height of } \\
\text { column or jet }\end{array}$}} & \multicolumn{2}{|c|}{ Approximate velocity } \\
\hline & & & & & & & & \multirow{2}{*}{$\begin{array}{c}\text { Velocity } \\
(f t / s)\end{array}$} & \multirow{2}{*}{$\begin{array}{l}\text { Height } \\
\text { range } \\
\text { (ft) }\end{array}$} \\
\hline & & & & (ft) & $\left(f t / l b^{1 / 3}\right)$ & (ft) & $\left(f t / l b^{1 / 3}\right)$ & & \\
\hline 1 left & 0.34 & 1.17 & \multicolumn{2}{|c|}{12.7 (near base) } & 7.43 & $\approx 140$ & $\approx 81.9$ & $\begin{array}{l}\geq 235 \\
316 \text { (jet) }\end{array}$ & $\begin{array}{c}0-47 \\
47-110\end{array}$ \\
\hline 1 right & 0.34 & 1.17 & \multicolumn{2}{|c|}{12.0 (near base) } & 7.02 & $\approx 140$ & $\approx 81.9$ & $\begin{array}{l}\geq 253 \\
298 \text { (jet) }\end{array}$ & $\begin{array}{c}0-51 \\
51-110\end{array}$ \\
\hline 1 middle & 0.34 & 1.93 & \multicolumn{2}{|c|}{$\begin{array}{l}11.4 \text { (near base } \\
\text { and mid-ht.) }\end{array}$} & 6.67 & 94 & 55.0 & $\begin{array}{r}\geq 108 \\
132\end{array}$ & $\begin{array}{r}0-22 \\
22-48\end{array}$ \\
\hline 2 left & 0.39 & 3.27 & \multicolumn{2}{|c|}{$\approx 32$} & $\approx 18.7$ & 54 & 31.6 & $\begin{array}{r}\geq 215 \\
63\end{array}$ & $\begin{array}{r}0-43 \\
43-56\end{array}$ \\
\hline 2 right & 0.39 & 3.27 & \multicolumn{2}{|c|}{$\approx 22$} & $\approx 12.9$ & 50 & 29.9 & $\begin{array}{r}\geq 226 \\
18\end{array}$ & $\begin{array}{r}0-45 \\
45-50\end{array}$ \\
\hline 2 middle & 0.39 & 3.98 & \multicolumn{2}{|l|}{-} & - & 47 & 27.5 & $\begin{array}{r}\geq 188 \\
18\end{array}$ & $\begin{array}{r}0-38 \\
38-43\end{array}$ \\
\hline 3 left & 0.39 & 0.56 & \multicolumn{2}{|c|}{$\begin{array}{l}15.5 \text { (near base) } \\
36 \text { (smoke crown) }\end{array}$} & $\begin{array}{l}9.06 \\
21.1\end{array}$ & 149 & 87.1 & $\begin{array}{l}\geq 286 \\
110 \\
124 \text { (jet) }\end{array}$ & $\begin{array}{c}0-57 \\
57-79 \\
79-104\end{array}$ \\
\hline 3 right & 0.39 & 0.56 & \multicolumn{2}{|c|}{$\begin{array}{l}13.0 \text { (near base) } \\
34 \quad \text { (smoke crown) }\end{array}$} & $\begin{array}{l}7.60 \\
19.9\end{array}$ & 130 & 76.0 & $\begin{array}{r}\geq 268 \\
96 \\
101 \text { (jet) }\end{array}$ & $\begin{array}{r}0-54 \\
54-73 \\
73-93\end{array}$ \\
\hline 3 middle & 0.39 & 0.56 & \multicolumn{2}{|c|}{$\begin{array}{l}13.9 \text { (near base) } \\
-\end{array}$} & $\begin{array}{l}8.13 \\
-\end{array}$ & 189 & 110.1 & $\begin{array}{l}\geq 288 \\
170 \\
147 \text { (jet) }\end{array}$ & $\begin{array}{c}0-58 \\
58-93 \\
93-122\end{array}$ \\
\hline 4 (\#1 camera) & 0.19 & 2.05 & 27 & $\begin{array}{l}\text { (near base and } \\
\text { at } 36-\mathrm{ft} \text { ht.) }\end{array}$ & 7.89 & 167 & 48.8 & $\begin{array}{l}\geq 180 \\
204 \\
284 \text { (jet) }\end{array}$ & $\begin{array}{c}0-36 \\
36-77 \\
77-134\end{array}$ \\
\hline 4 (\#2 camera) & 0.19 & 2.05 & 26 & $\begin{array}{l}\text { (near base and } \\
\text { at } 33-\mathrm{ft} \text { ht.) }\end{array}$ & 7.60 & - & - & $\begin{array}{l}198 \\
140\end{array}$ & $\begin{array}{r}0-40 \\
40-68\end{array}$ \\
\hline 6 left & 0.41 & 1.17 & $\begin{array}{l}16 \\
16\end{array}$ & $\begin{array}{l}\text { (near base) } \\
\text { (at } 70-\mathrm{ft} \text { ht.) }\end{array}$ & $\begin{array}{l}9.36 \\
9.36\end{array}$ & $\approx 135$ & $=78.9$ & $\begin{array}{l}\geq 317 \\
248 \text { (jet) }\end{array}$ & $\begin{array}{c}0-63 \\
63-117\end{array}$ \\
\hline 6 right & 0.41 & 1.17 & $\begin{array}{l}16 \\
18\end{array}$ & $\begin{array}{l}\text { (near base) } \\
\text { (at 67-ft ht.) }\end{array}$ & $\begin{array}{r}9.36 \\
10.53\end{array}$ & $\approx 129$ & $\approx 75.4$ & $\begin{array}{l}\geq 298 \\
157 \text { (jet) }\end{array}$ & $\begin{array}{r}0-60 \\
60-94\end{array}$ \\
\hline 6 middle & 0.41 & 1.17 & $\begin{array}{l}16 \\
16\end{array}$ & $\begin{array}{l}\text { (near base) } \\
\text { (at 68-ft ht.) }\end{array}$ & $\begin{array}{l}9.36 \\
9.36\end{array}$ & $\approx 127$ & $\approx 74.3$ & $\geq 277$ & $14-71$ \\
\hline 7 left outer & 0.18 & 2.05 & 31 & (mid-ht.) & 9.06 & 168 & 49.1 & 230 & $130-160$ \\
\hline 7 left inner & 0.18 & 2.05 & 29 & (mid-ht.) & 8.48 & 189 & 55.3 & 275 & $130-160$ \\
\hline 7 middle & 0.18 & 2.05 & 29 & (mid-ht.) & 8.48 & 207 & 60.5 & 283 & $130-160$ \\
\hline 7 right inner & 0.18 & 2.05 & 29 & (mid-ht.) & 8.48 & 207 & 60.5 & 277 & $130-160$ \\
\hline 7 right outer & 0.18 & 2.05 & 30 & (mid-ht.) & 8.77 & 173 & 50.6 & 211 & $130-160$ \\
\hline
\end{tabular}

each eruption was measured frame by frame on a 20 -in. TV screen, so that graphs of height vs time could be plotted. The framing rate was $30 / \mathrm{s}$ so that the interval between successive measurements was $33.3 \mathrm{~ms}$.

Results of the video measurements are shown graphically in Appendix B (Fig. B1-B9). Velocities were measured from these graphs, giving the results shown in Table 2.

The video tapes were not used to measure the maximum height and maximum diameter of the eruptions because still photographs from the motor-driven camera provided greater clarity and better contrast. The video images of the eruptions, which tend to have diffuse (fuzzy) edges, do not always show up clearly against snow-covered ice or against a light sky. The maximum height of the eruption was not always in the frame of view.

\section{DATA FROM MOTOR-DRIVEN CAMERAS}

The motor-driven cameras were ordinary SLR 35-mm cameras (Olympus OM-2) fitted with battery-powered drive units. With ordinary films of moderately high speed, there was no difficulty in operating at high shutter speeds, since the lighting was bright (typically sun on snow).

The camera was aimed at the shot points, including in the field of view the pair of rocks that 
had been set at a measured distance apart on a line perpendicular to the sight line and through the shot point. The intention was to have two cameras recording each blast, one to give details of the initial stage of the eruption and the other to cover the complete height range of the eruption. However, one camera malfunctioned during most of the shots (the shutter jammed). The cameras were triggered manually on the countdown for the blast, which was fired electrically. Air temperatures were mild (usually slightly above freezing), and there were no indications that the cameras suffered from stiffening of lubricants or film.

Measurements were made on the resulting photographs to obtain the maximum diameter and the maximum height of each eruption. Table 3 gives these dimensions, and samples of the photographs are shown in Appendix A.

Wherever possible, the first two or three photographs in a sequence were used to obtain an estimate of vertical velocity from the height measurements. The nominal advance rate of the motor drives was 5 frames per second, giving a nominal time interval of $200 \mathrm{~ms}$ between exposures. The cameras and drive units were calibrated back at the laboratory at an appropriate temperature, and the actual framing intervals were found to be 204 $\mathrm{ms}$ for the camera that functioned continuously and $235 \mathrm{~ms}$ for the faulty camera. Both cameras reached steady speed after one frame; the faulty camera was very slow for the first frame but the other camera was only slightly below the rated speed for the first frame advance. The velocity estimates are given in Table 3.

Photo coverage of the blasts was incomplete. This was due partly to failure of one camera, as already mentioned, and partly because the explosions were triggered, either prematurely or late, by inexperienced troops using primitive equipment (the operation was also a training exercise for the troops).

\section{DISCUSSION}

The values listed in Table 2 as "initial velocity" are eruption velocities that actually apply over a large height range, mostly in excess of $5 \mathrm{~m}$ and in some cases over $17 \mathrm{~m}$ (Fig. B1-B9). These "initial velocities" should not be confused with the true initial velocities that are measured in the shockinduced spray domes from standard underwater explosions. Having stressed this distinction, the velocities from Table 2 are related to scaled charge depth (Table 4) and compared with theoretical
Table 4. Initial velocity and scaled charge depth.

\begin{tabular}{|c|c|c|c|}
\hline $\begin{array}{c}\text { Shot } \\
\text { no. }\end{array}$ & $\begin{array}{c}\text { Scaled } \\
\text { charge } \\
\text { depth } \\
\left(f t / l b^{1 / 3}\right)\end{array}$ & $\begin{array}{l}\text { Initial vertical } \\
\text { velocity from } \\
\text { video records } \\
(f t / s)\end{array}$ & $\begin{array}{c}\text { Initial vertical } \\
\text { velocity from } \\
\text { motor-driven } \\
\text { camera } \\
(\mathrm{ft} / \mathrm{s})\end{array}$ \\
\hline 1 left outer & 1.17 & 215 & 235 \\
\hline 1 right & 1.17 & 232 & 253 \\
\hline 1 middle & 1.93 & 161 & 108 \\
\hline 2 left & 3.27 & 108 & 215 \\
\hline 2 right & 3.27 & 103 & 268 \\
\hline 2 middle & 3.98 & 162 & 288 \\
\hline 3 left & 0.56 & 516 & 286 \\
\hline 3 right & 0.56 & 562 & 268 \\
\hline 3 middle & 0.56 & 556 & 288 \\
\hline 4 & 2.05 & 101 & 180,198 \\
\hline 5 left & 1.17 & 260 & - \\
\hline 5 right & 1.17 & 274 & - \\
\hline 5 middle & 1.17 & 272 & - \\
\hline 6 left & 1.17 & 268 & 317 \\
\hline 6 right & 1.17 & 272 & 298 \\
\hline 6 middle & 1.17 & 299 & - \\
\hline 7 left outer & 2.05 & 159 & - \\
\hline 7 left inner & 2.05 & 154 & - \\
\hline 7 middle & 2.05 & 184 & - \\
\hline 7 right inner & 2.05 & 177 & - \\
\hline 7 right outer & 2.05 & 152 & - \\
\hline
\end{tabular}

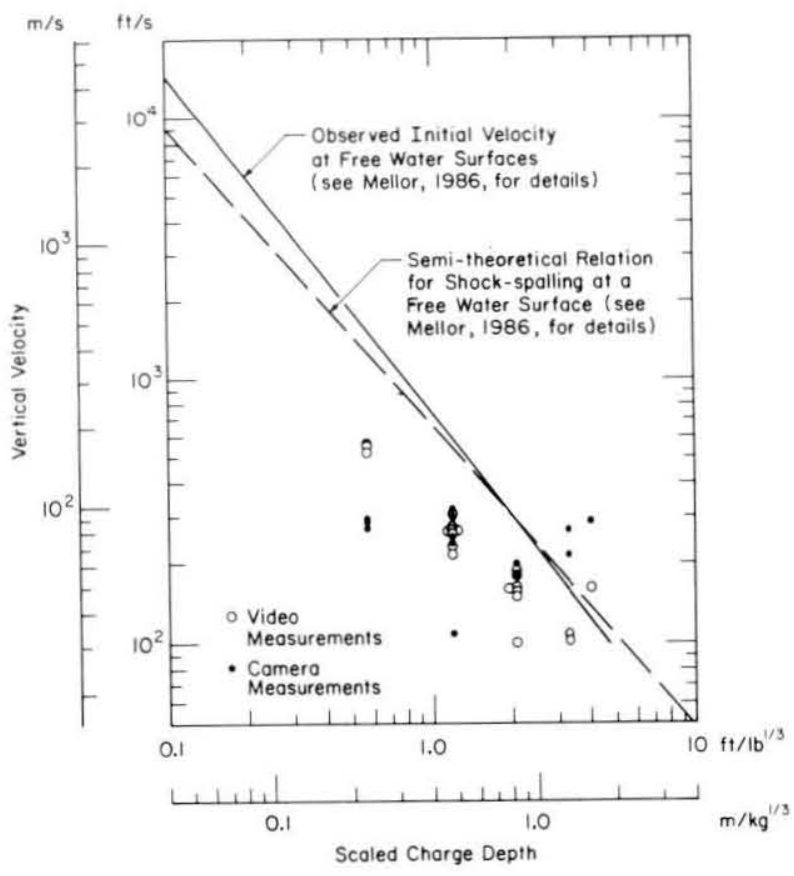

Figure 1. Initial vertical velocity plotted against 


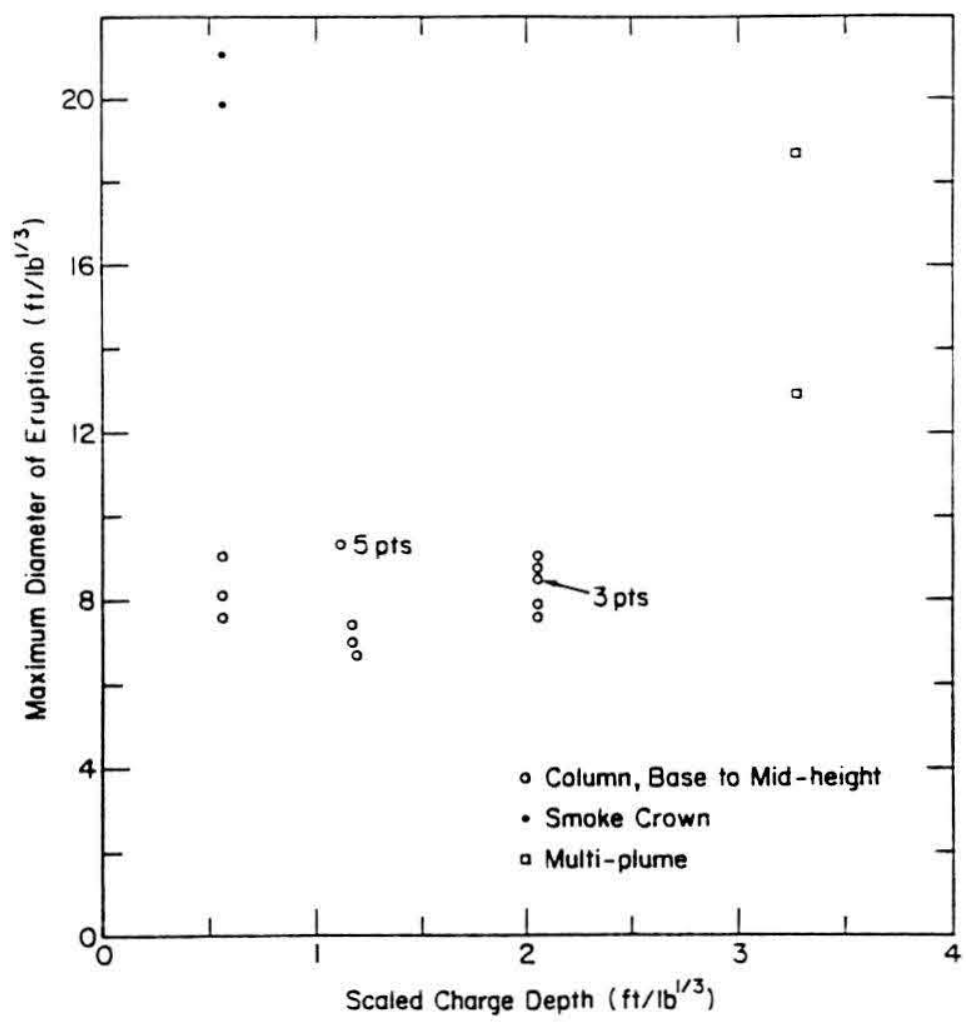

Figure 2. Scaled maximum diameter of the eruption plotted against scaled charge depth.

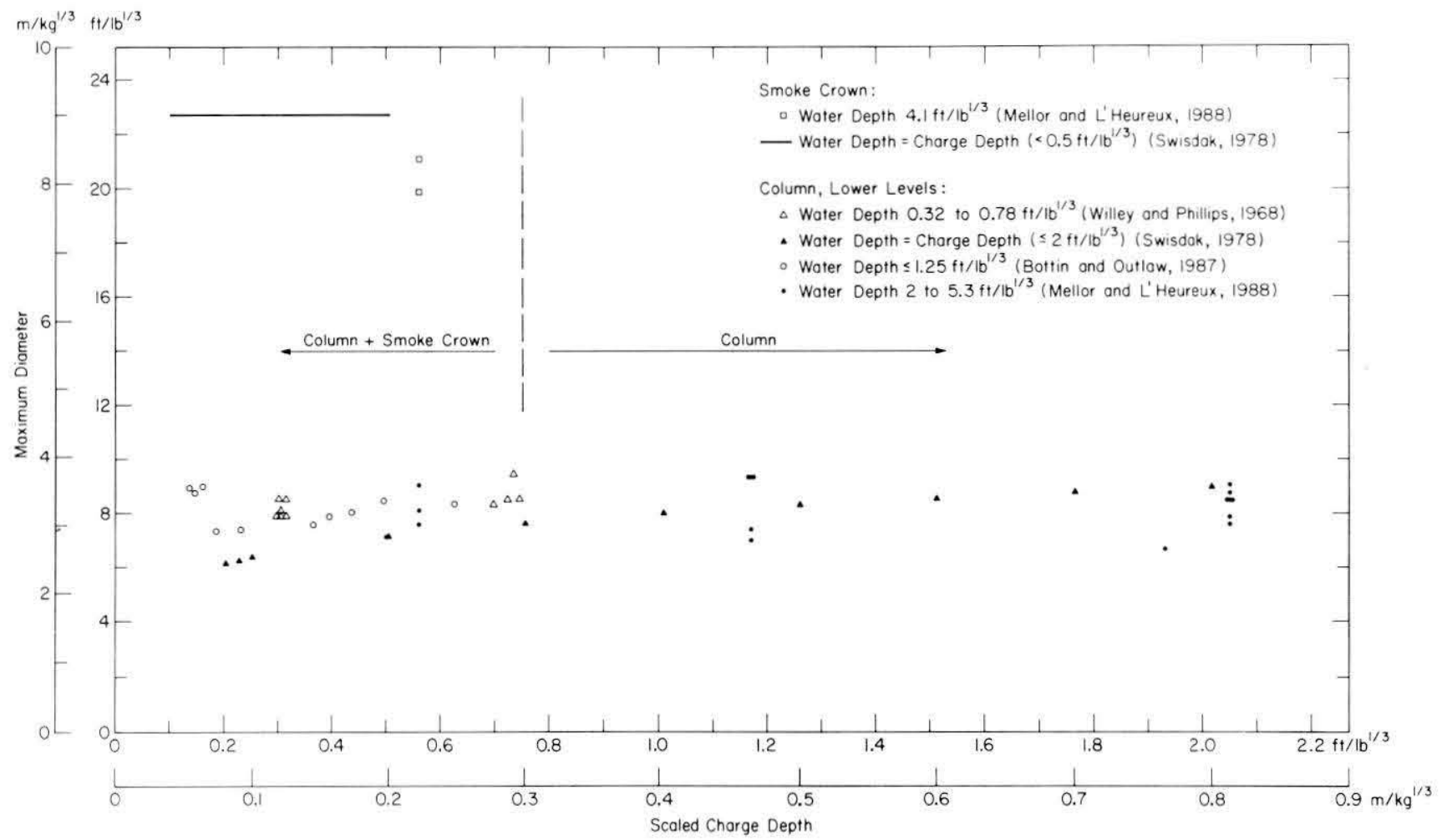

Figure 3. Comparison of diameter data with results for ice-free water. 


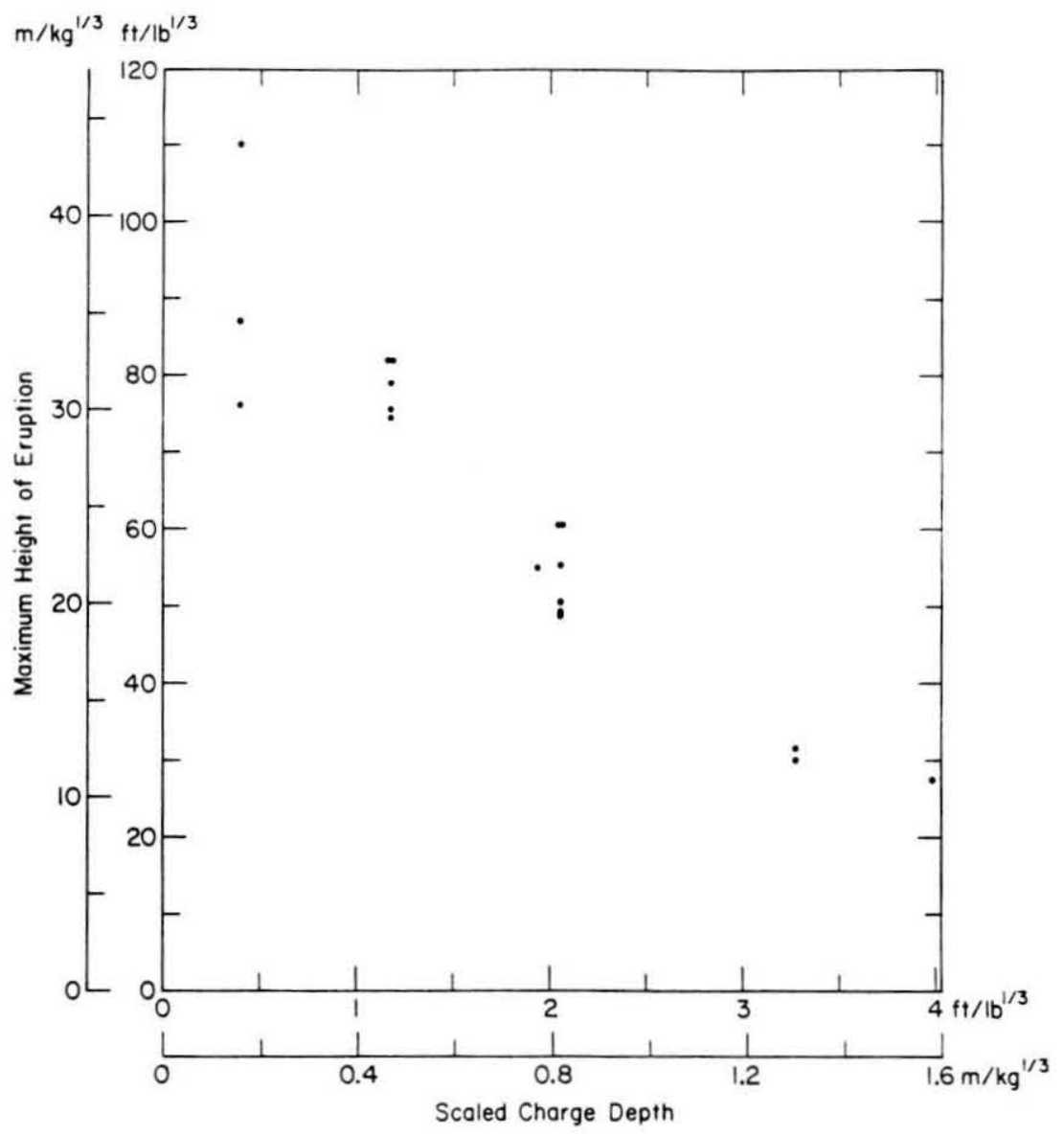

Figure 4. Scaled maximum height of the eruption plotted against scaled charge depth (using cube-root scaling for charge depth).

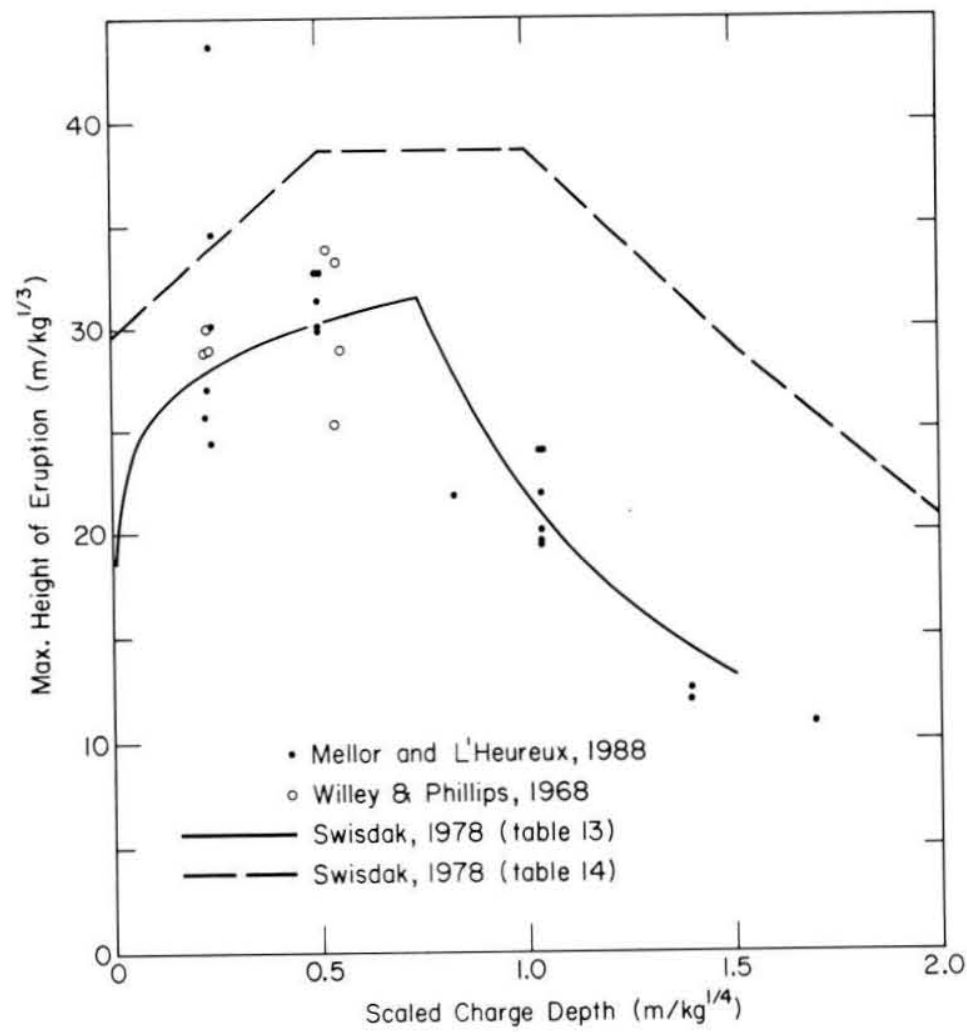

Figure 5. Comparison of height data with results for ice-free water (using fourth-root scaling for charge depth). 
shock-spalling velocities for a free water surface and with observed initial velocities for ordinary underwater explosions (Fig. 1). The discrepancies between camera and video measurements in shots 2 and 3 have not been explained; one possibility is that the motor drive or the shutter malfunctioned.

For relatively large-scaled charge depths, the emergence velocities for the ice eruptions cluster around the trend lines for ejection velocities from free water surfaces. At smaller scaled charge depths, the observed emergence velocities for the ice eruptions were smaller than the initial vertical velocities on free water surfaces.

The diameter of the eruption, as given in Table 3 , is shown graphically in Figure 2. Most of the eruptions were of columnar form, and the maximum diameters were in good agreement with comparable measurements made in shallow ice-free water (Fig. 3). One set of shallow-depth charges produced smoke crowns, for which the maximum diameters (Fig. 3) were not far from the values given by Swisdak (1978).

The maximum height of the eruption is plotted against charge depth in Figure 4. A comparison with comparable published data for ice-free water is given in Figure 5. Apart from two high values that were observed in shot 3 , the agreement with data for ice-free water is good.

\section{REFERENCES}

Bottin, R.R. and D.G. Outlaw (1987) Explosiongenerated waves in shallow water. USA Waterways Experiment Station, Miscellaneous Paper CERC-87-13.

Mellor, M. (1986) Blasting and blast effects in cold regions. Part II. Underwater explosions. USA Cold Regions Research and Engineering Laboratory, Special Report 86-16.

Swisdak, M.M. (1978) Explosion effects and properties. Part II. Explosion effects in water. Naval Surface Weapons Center, Technical Report 76-116.

Wiley, R.L. and D.E. Phillips (1968) Surface phenomena measurements and experimental procedures in 4000-lb HBX-1 shallow underwater explosive tests (Project “HEAT"). U.S. Naval Ordnance Laboratory, White Oak, Silver Spring, Maryland, NOLTR 68-74. 


\section{APPENDIX A: SELECTION OF PHOTOGRAPHS \\ FROM MOTOR-DRIVEN CAMERAS}

Within each sequence of photographs, the nominal interval between frames is $20 \mathrm{~ms}$. The actual framing interval was $204 \mathrm{~ms}$ for all sequences except (3); for (e) the interval was 235 ms.

In most cases, frames from the end of the sequence are not shown here. The frames omitted are those where material is falling back from the highest levels.
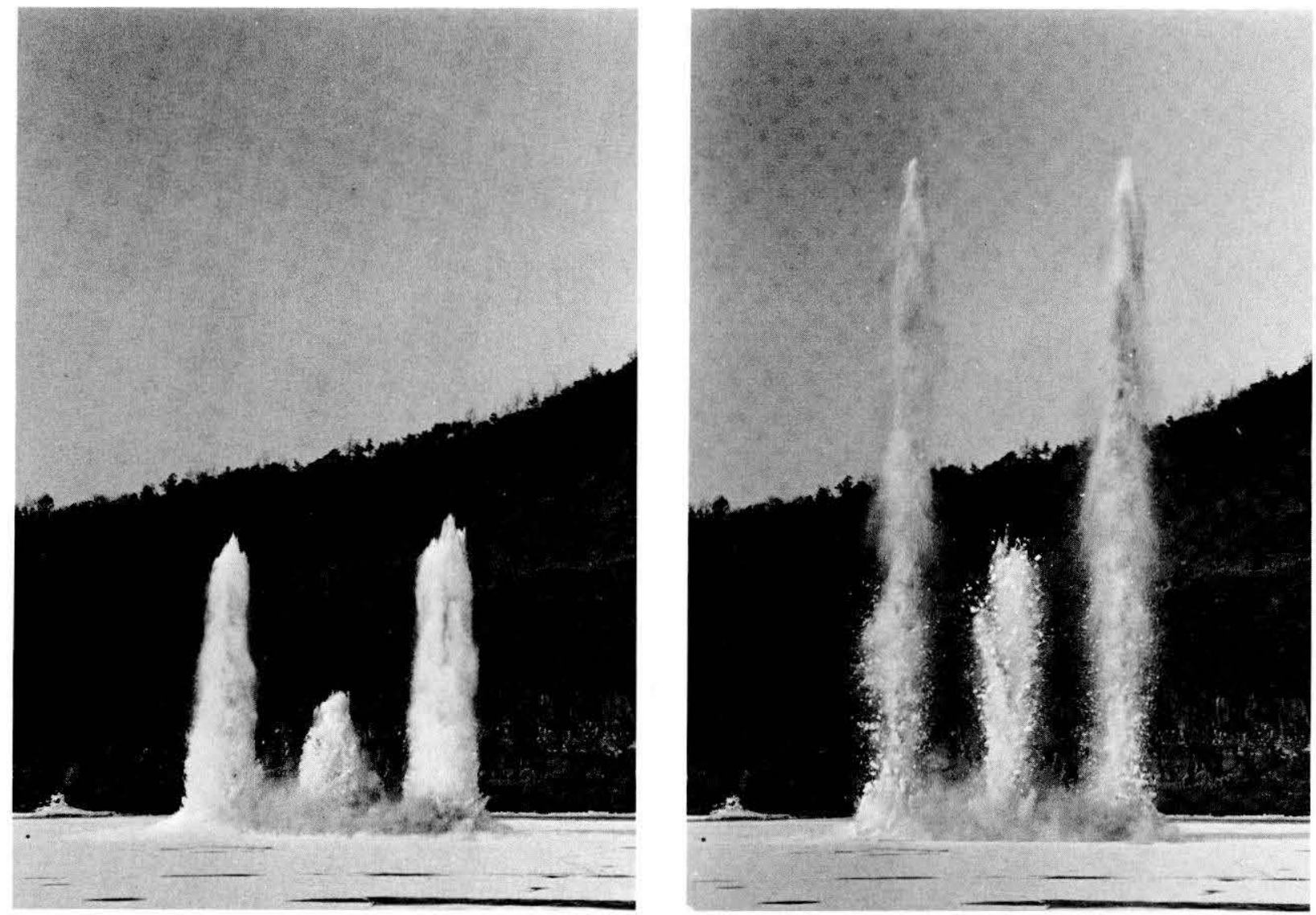

Figure Al. Six-frame sequence of shot no. 1 (2-second duration). 


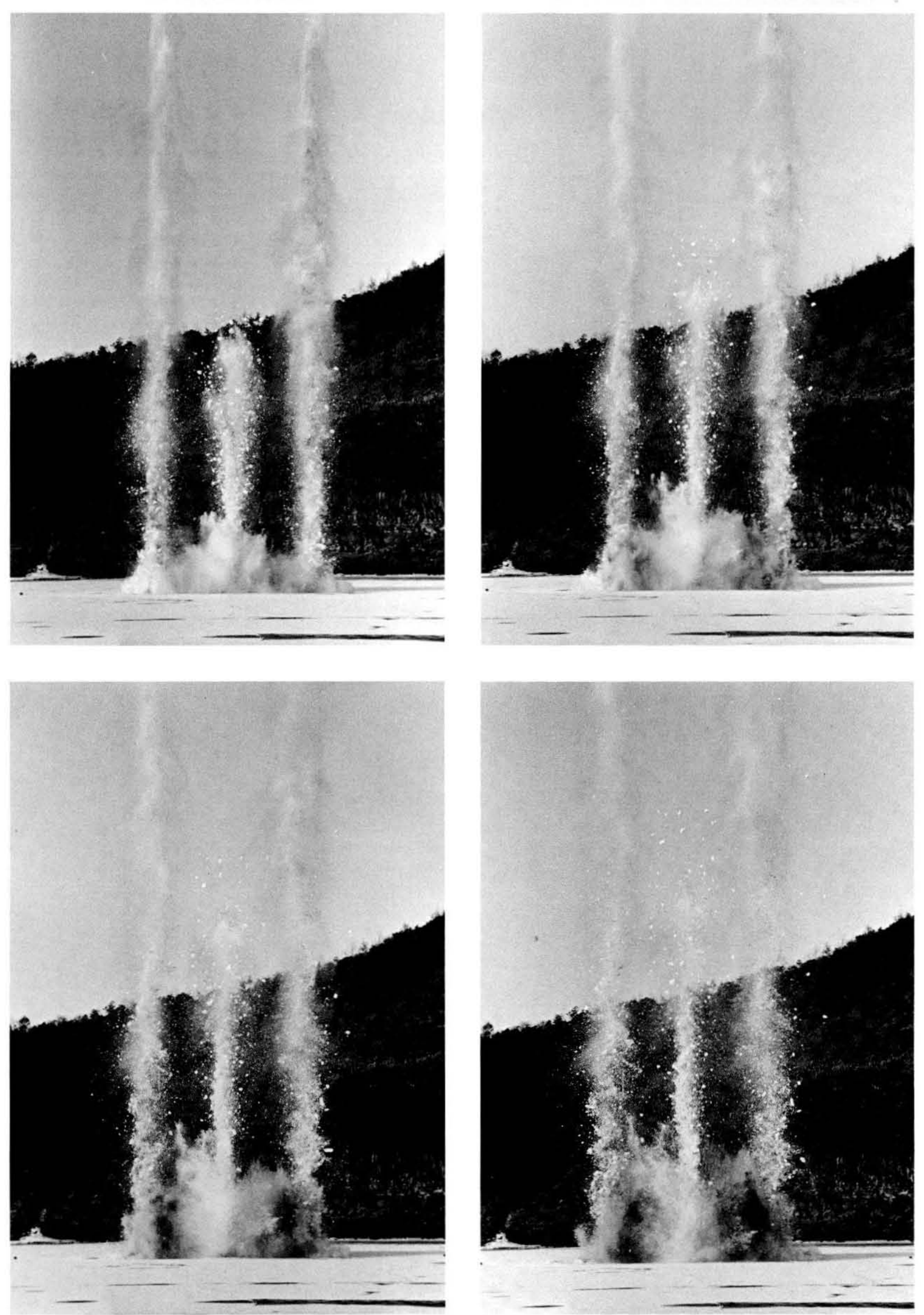

Figure Al (cont'd). Six-frame sequence of shot no. 1 (2-second duration). 

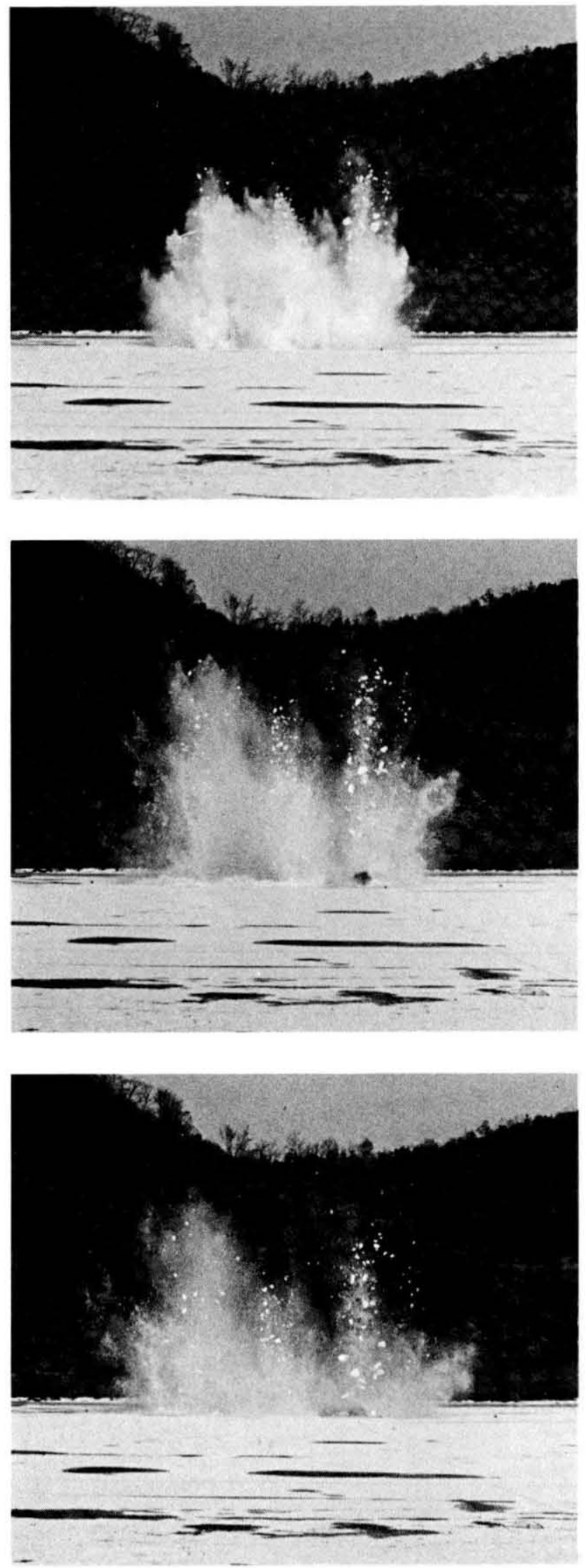

Figure A2. Three-frame sequence of shot no. 2. 

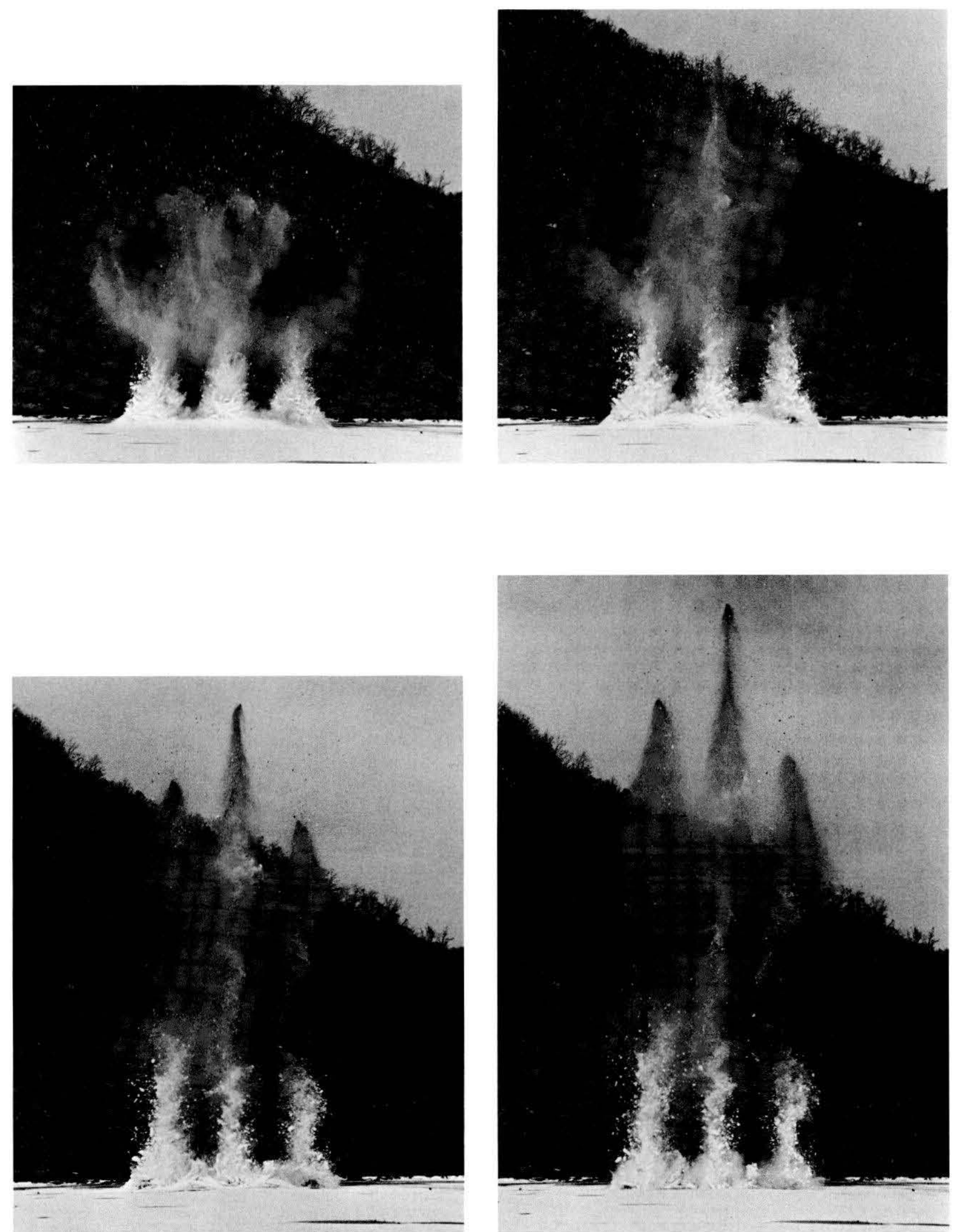

Figure A3. Six-frame sequence of shot no. 3. 

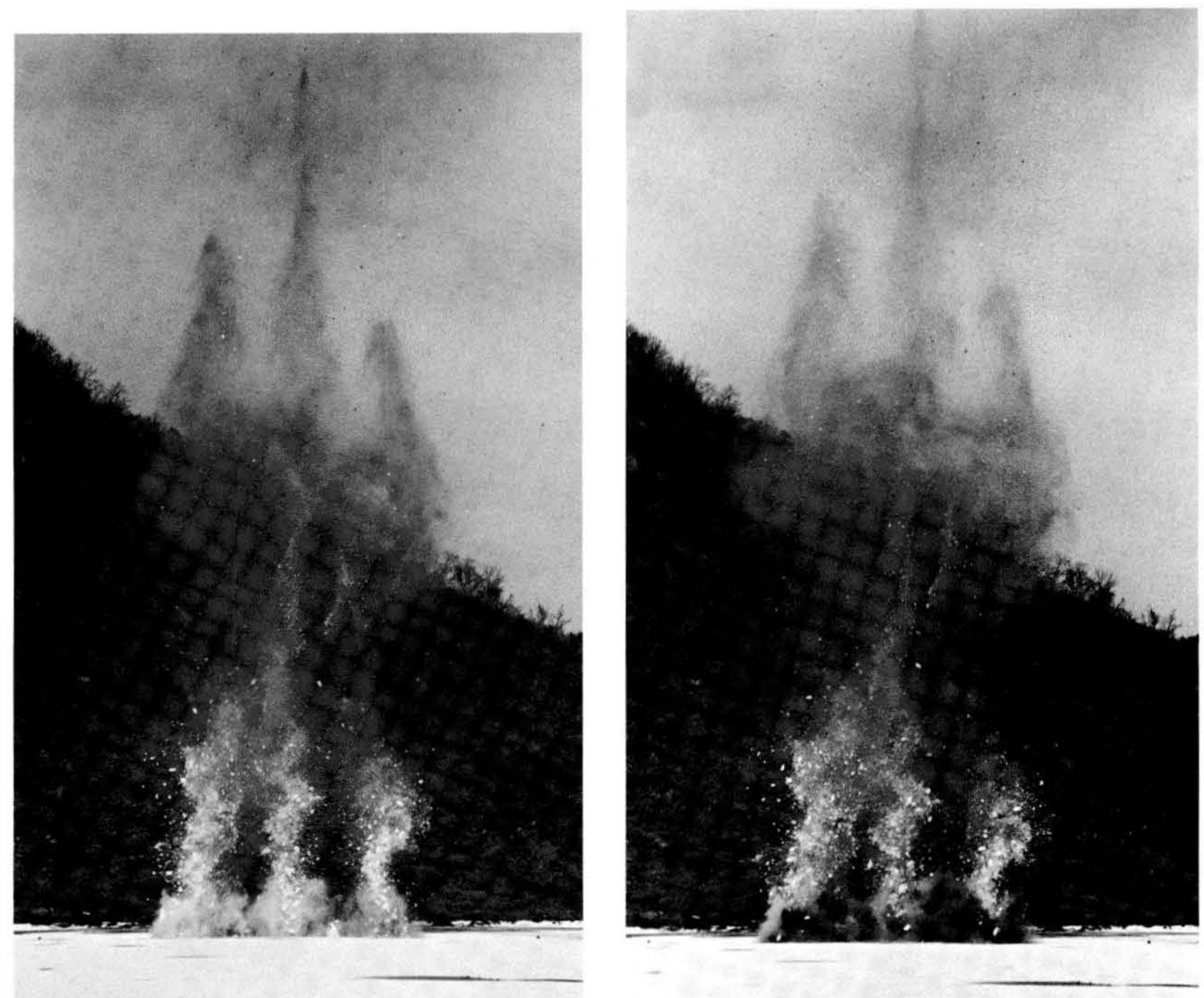

Figure A3 (cont'). 

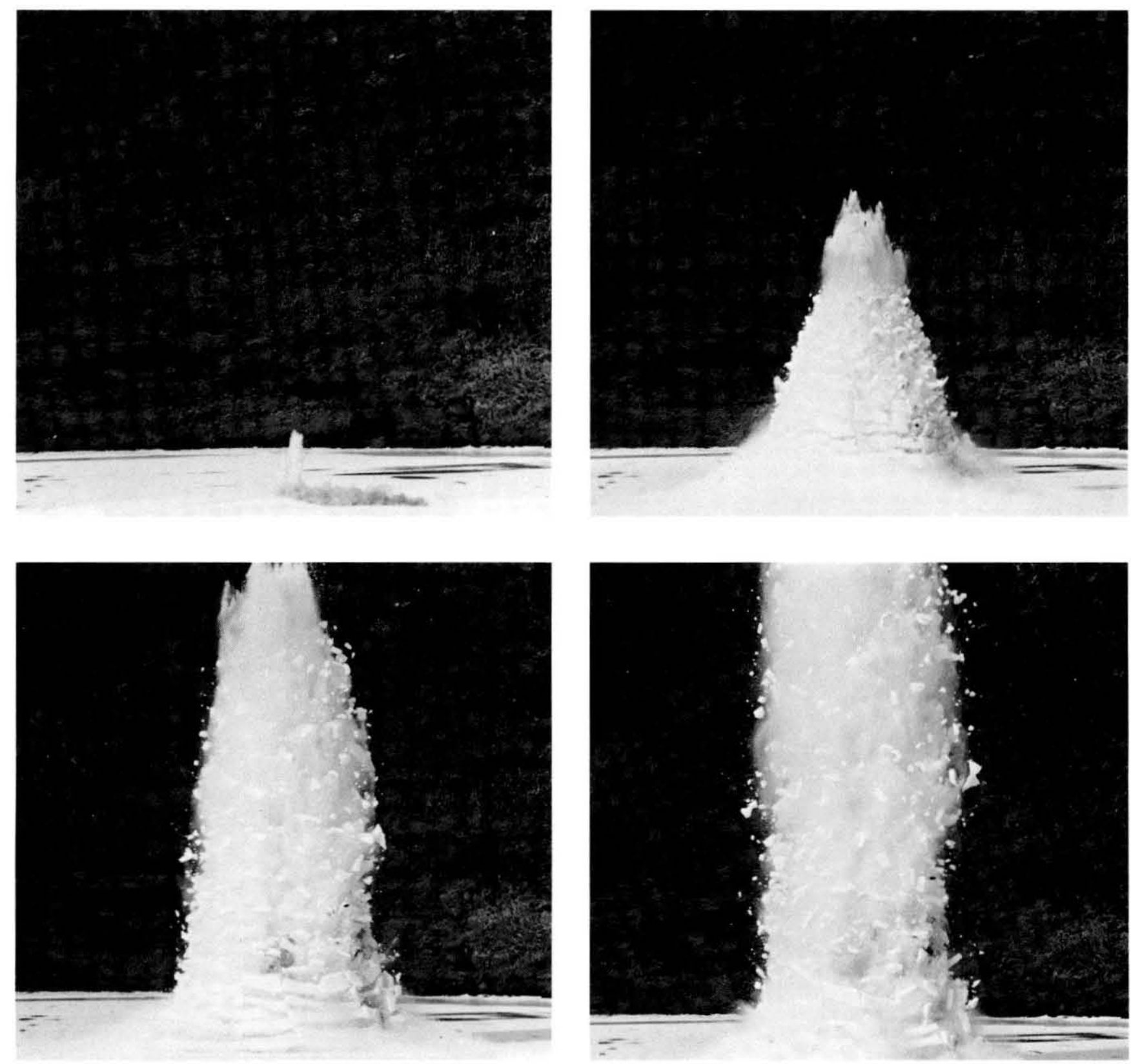

Figure A4. Six-frame sequence of shot no. 4 (camera no. 1). 

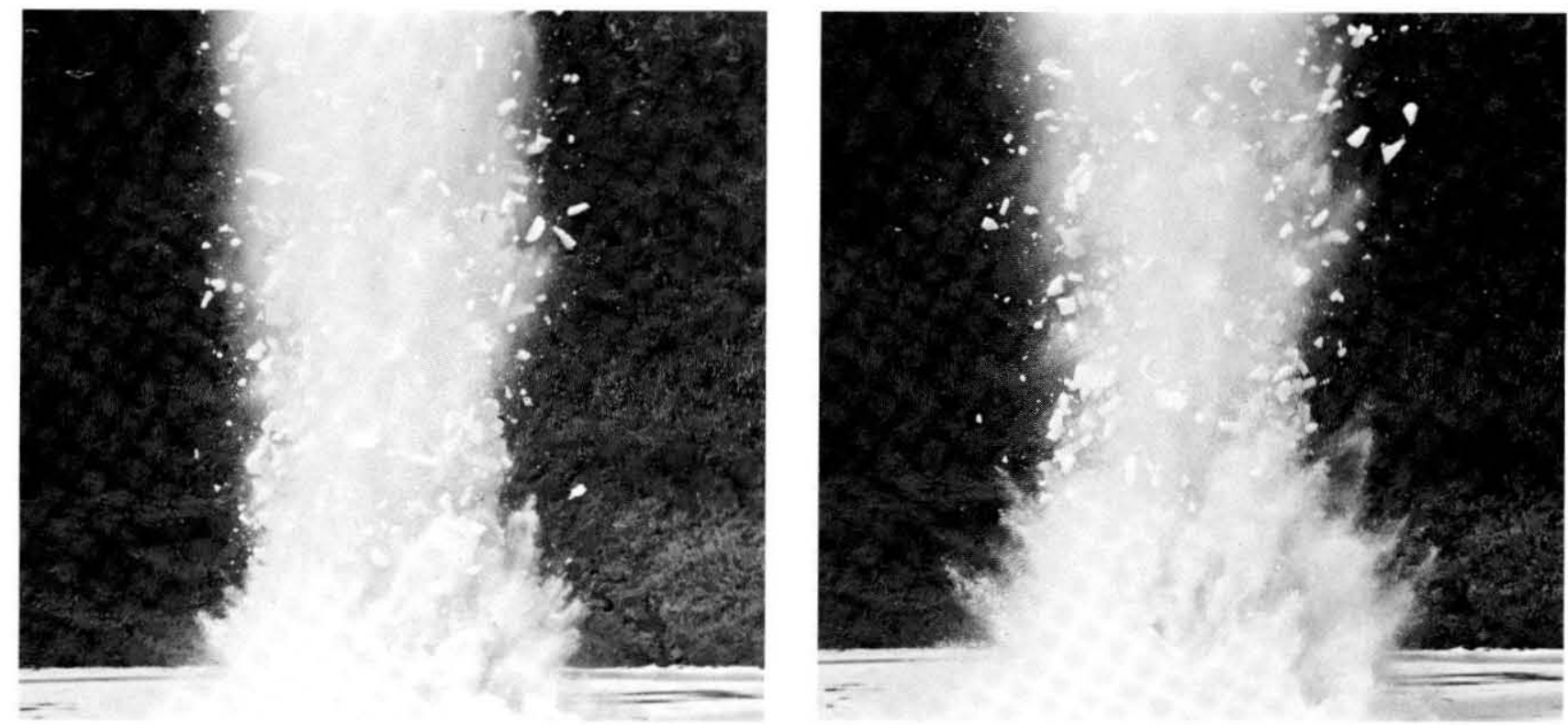

Figure A4 (cont'd). 

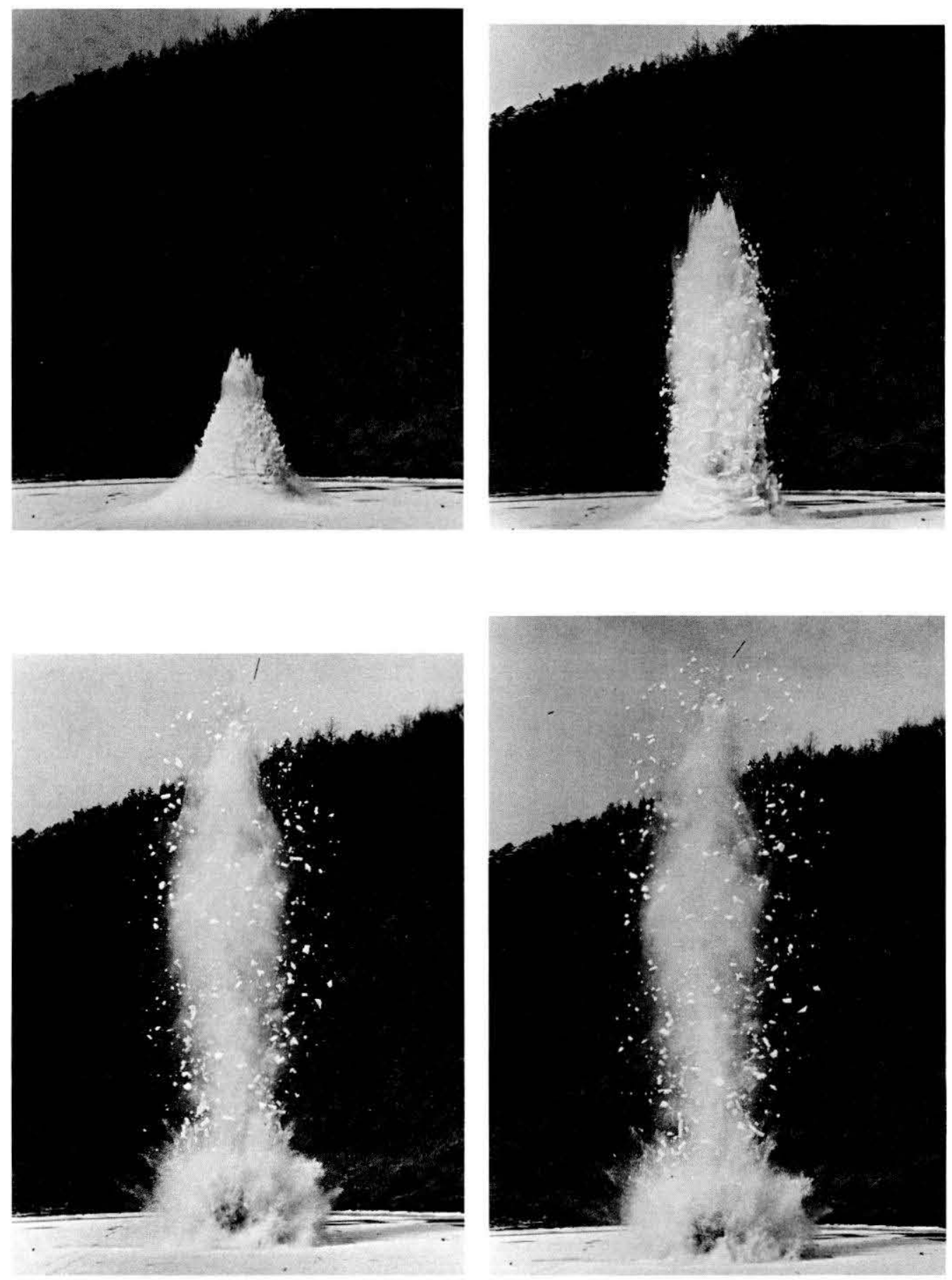

Figure A5. Six-frame sequence of shot no. 4 (camera no. 2). 


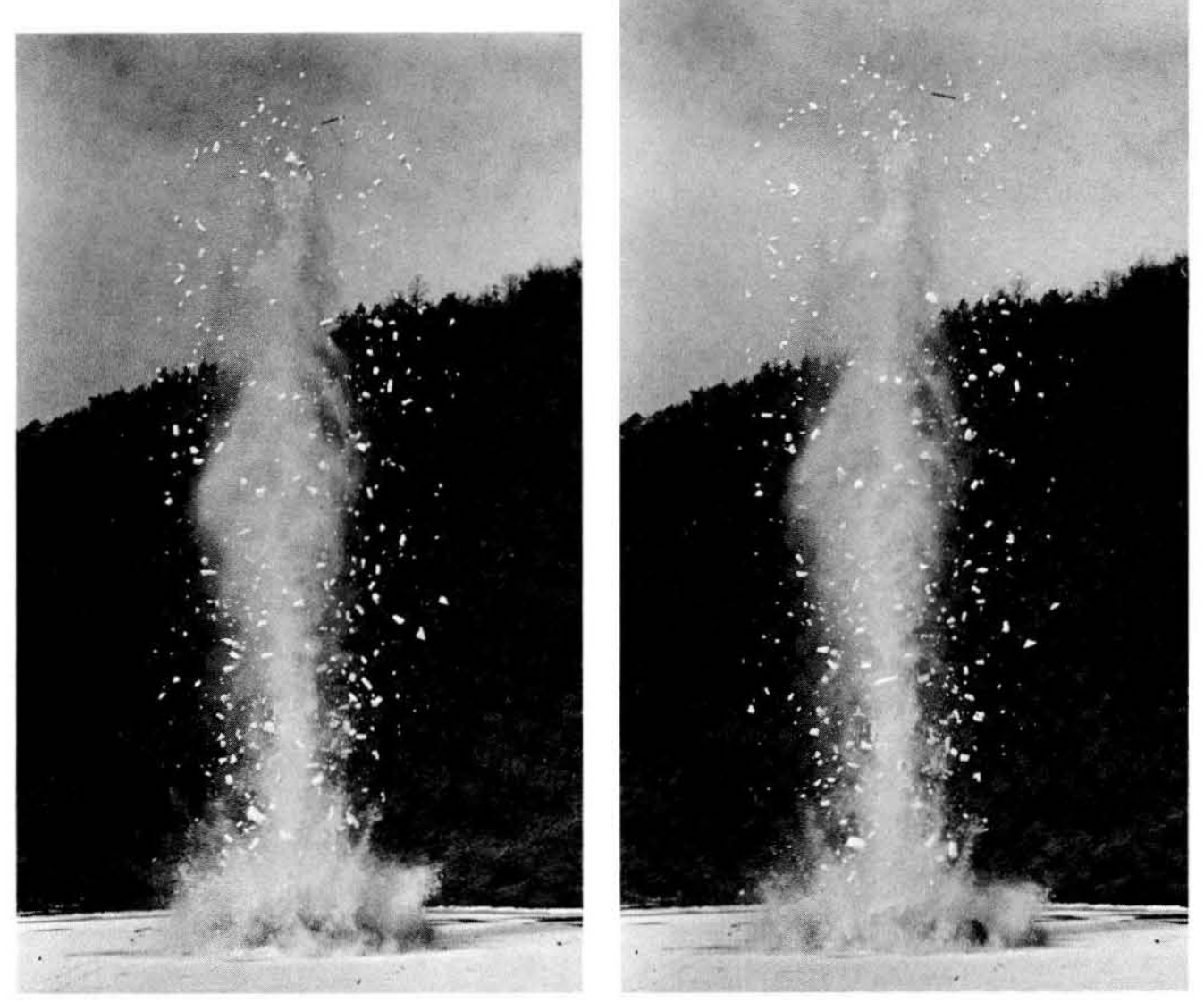

Figure A5 (cont'd). 

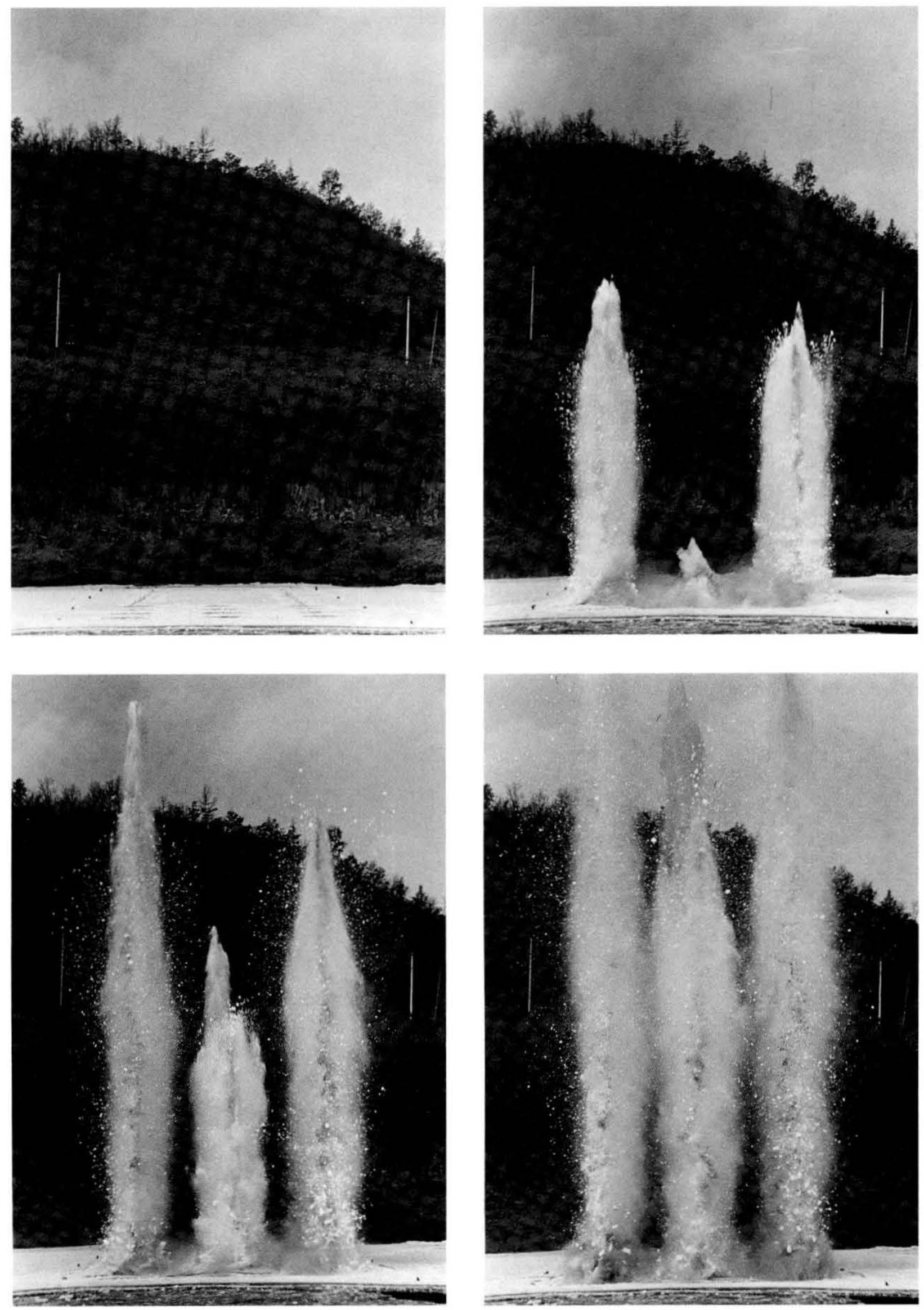

Figure A6. Six-frame sequence of shot no. 6. 

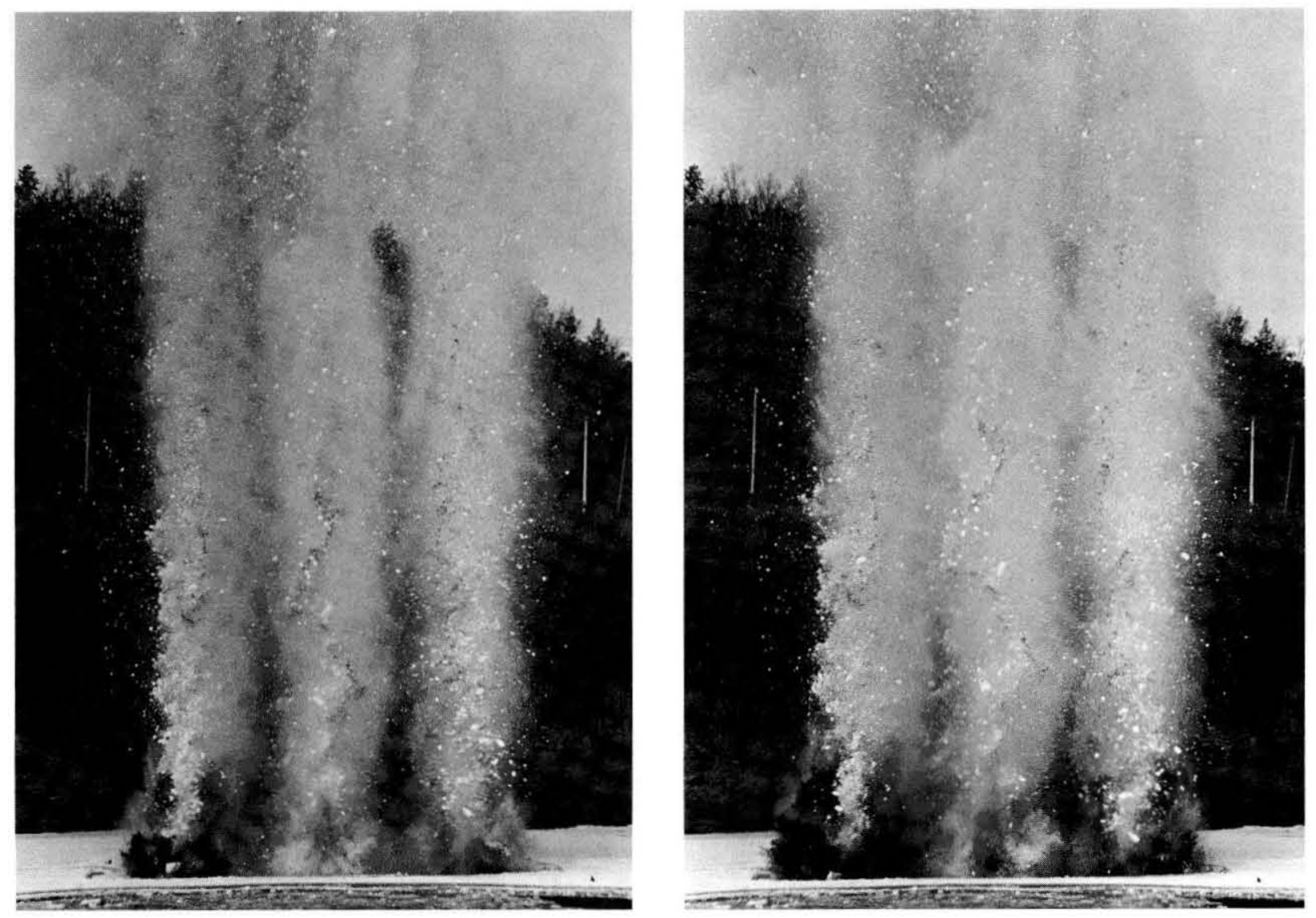

Figure A6 (cont'd). 

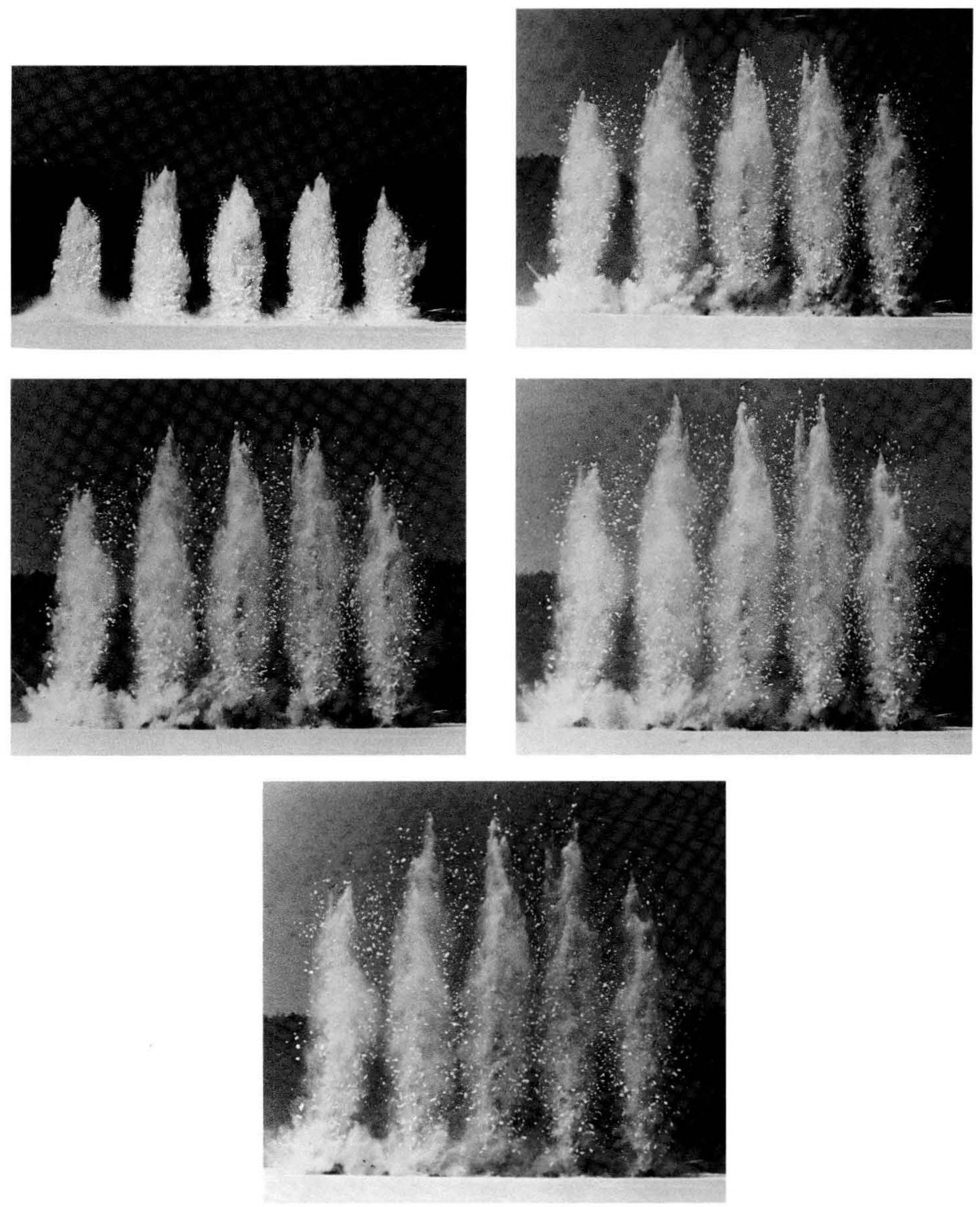

Figure A7. Seven-frame sequence of shot no. 7. 

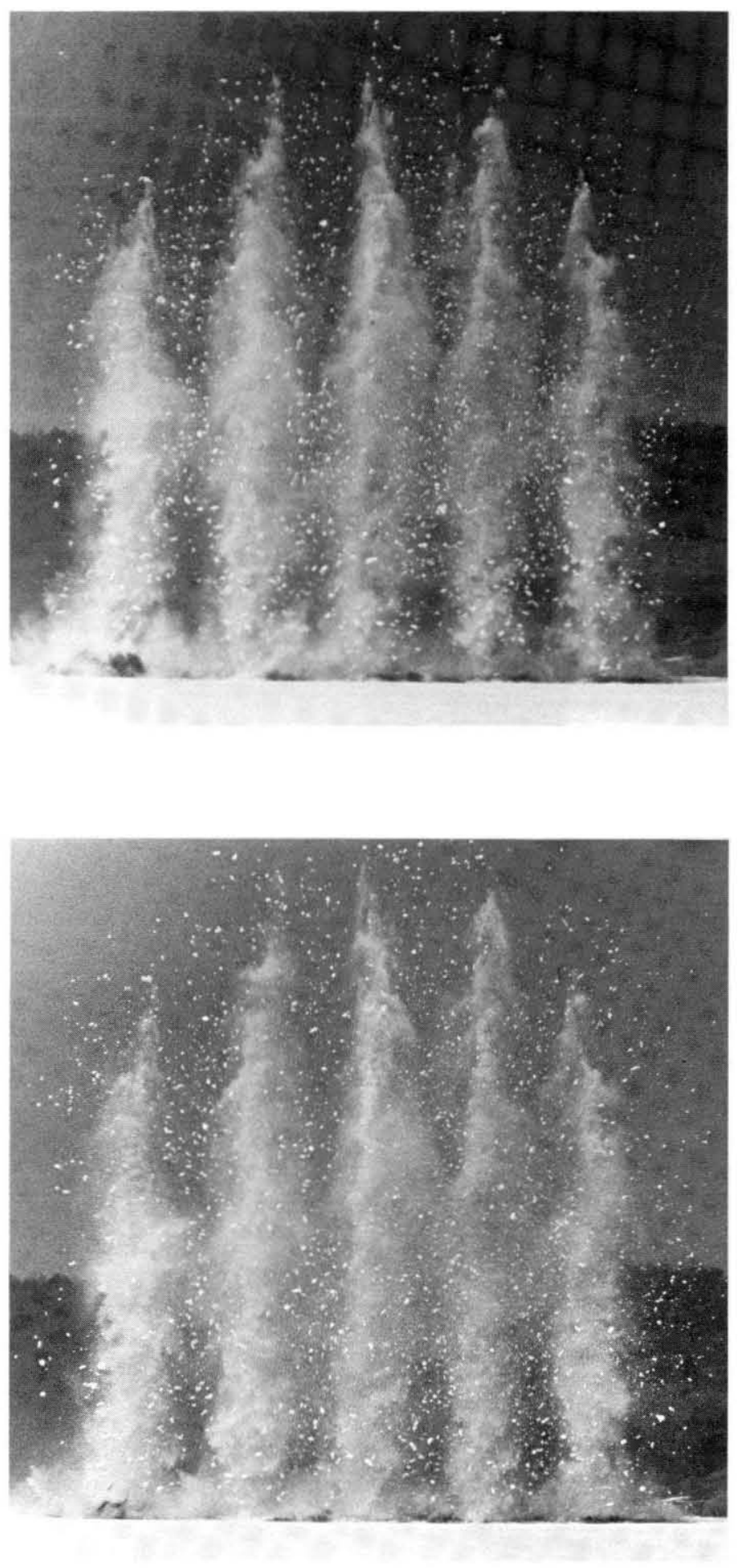

Figure A7 (cont'd). 


\section{APPENDIX B: VERTICAL DISPLACEMENT PLOTTED AGAINST TIME FOR THE VIDEO RECORDS}

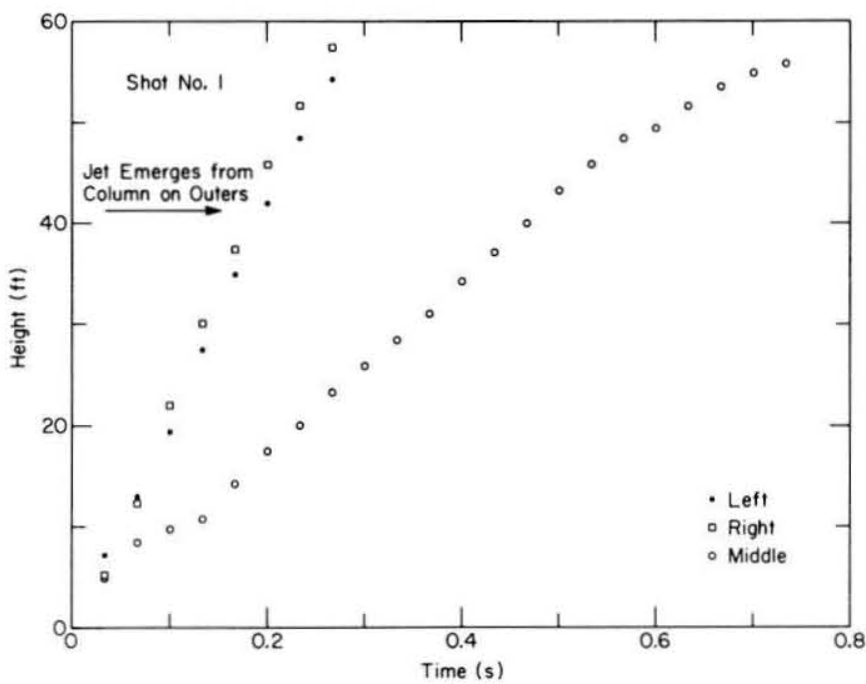

Figure B1. Data for shot no. 1 .

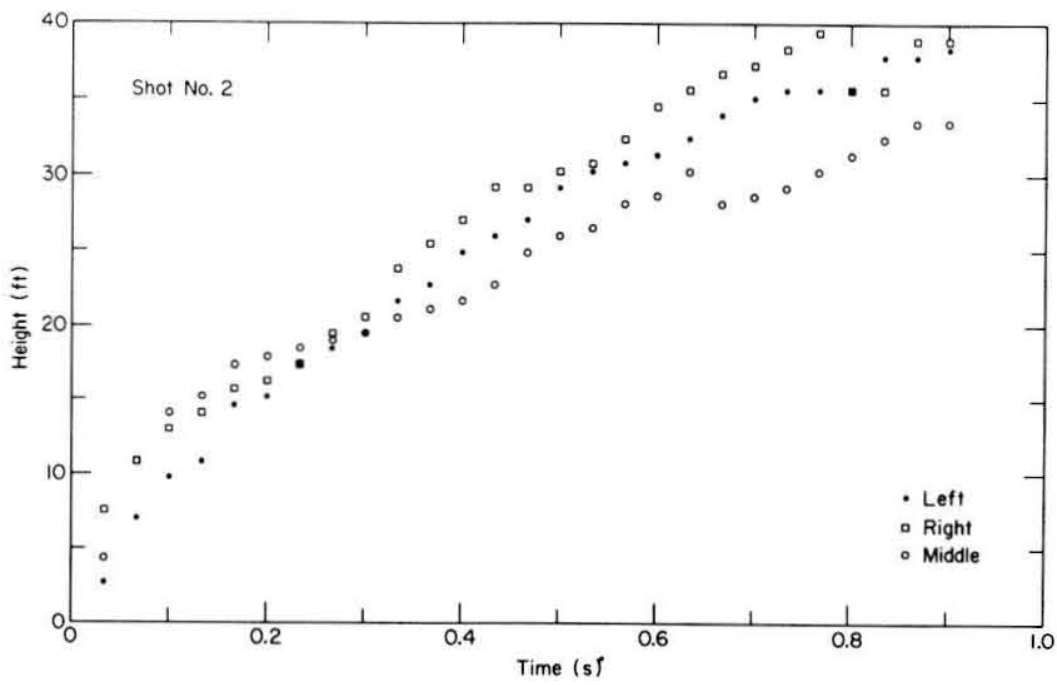

Figure B2. Data for shot no. 2 (the break in the trace for the middle explosion is caused by one part of the plume dying out and being overtaken by a more energetic spurt). 


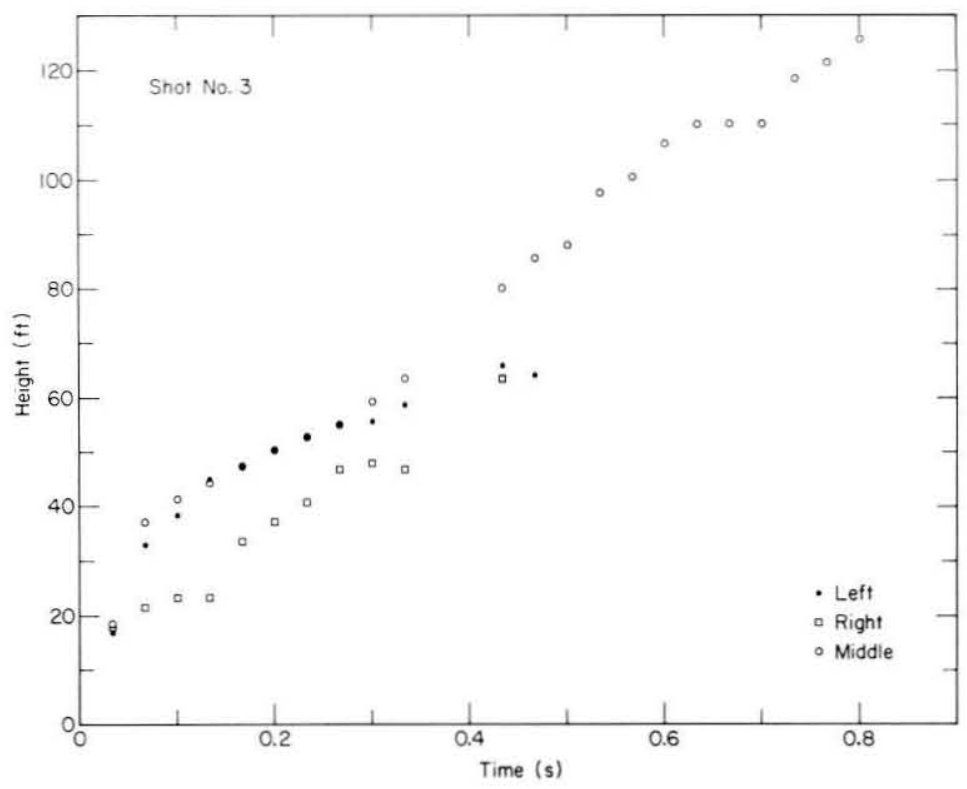

Figure B3. Data for shot no. 3 (the gap in this and other records is caused by loss of contrast in the video record).

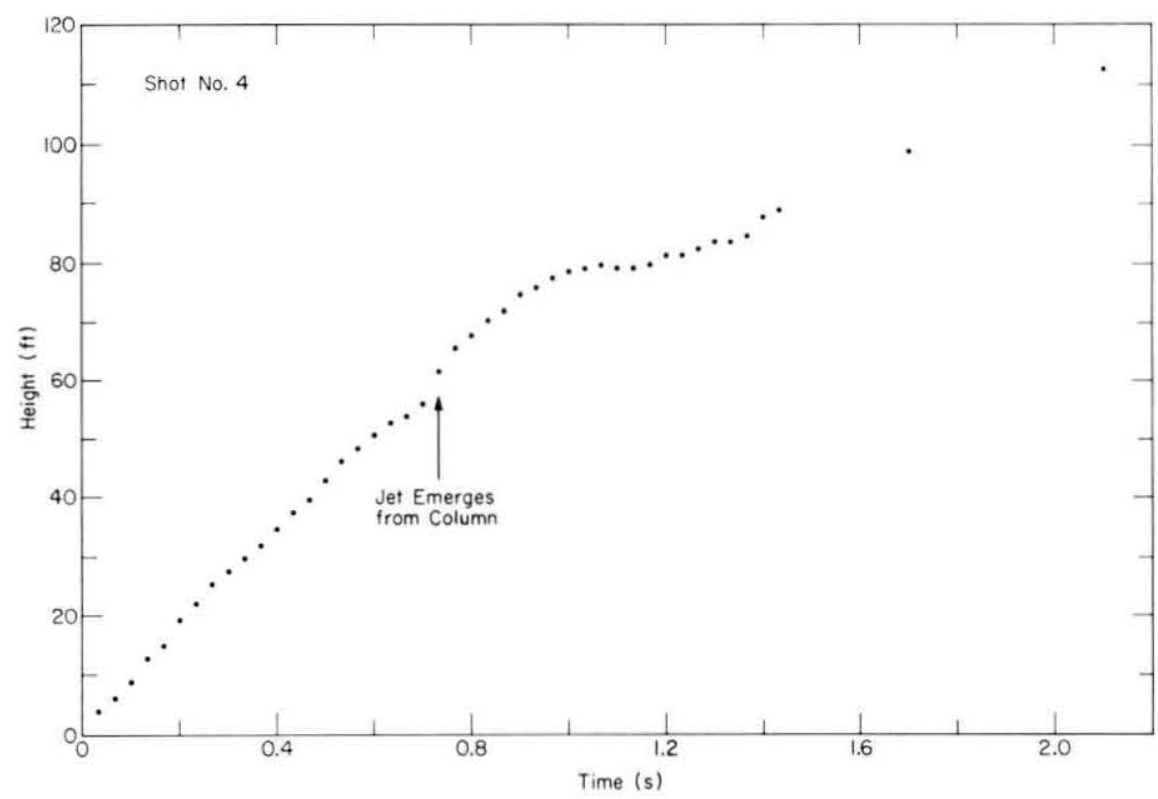

Figure B4. Data for shot no. 4. 


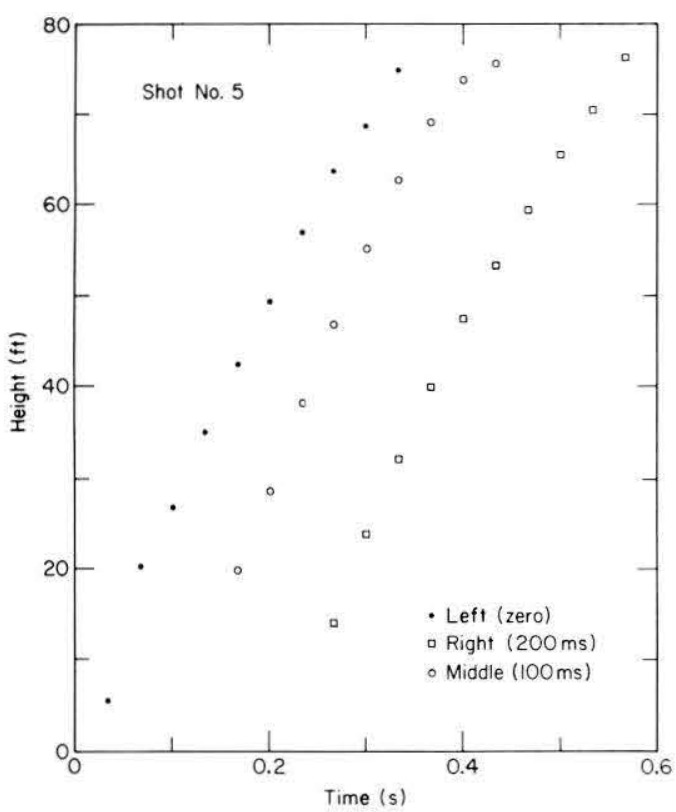

Figure B5. Data for shot no. 5.

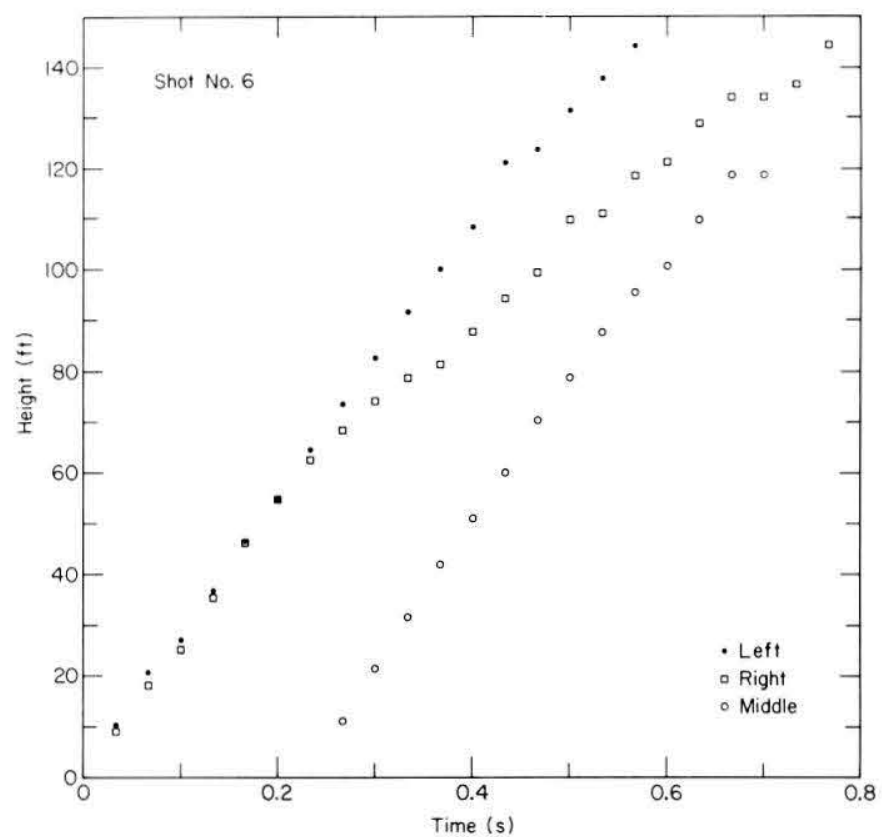

Figure B6. Data for shot no. 6.

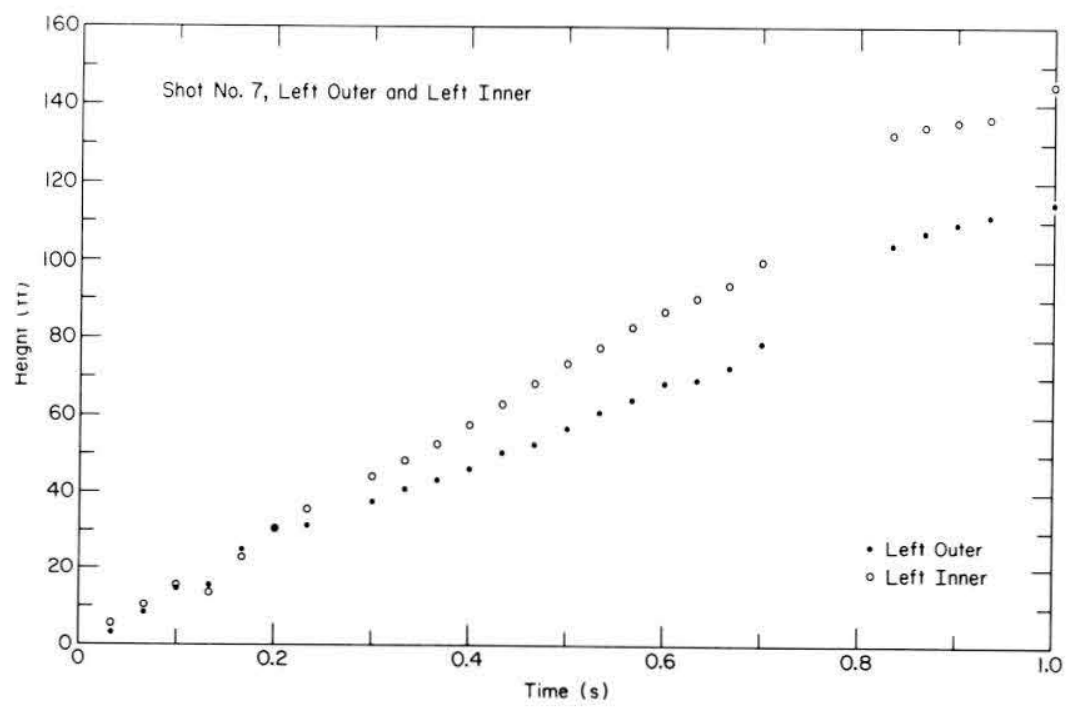

Figure B7. Data for right outer and right inner of shot no. 7 . 


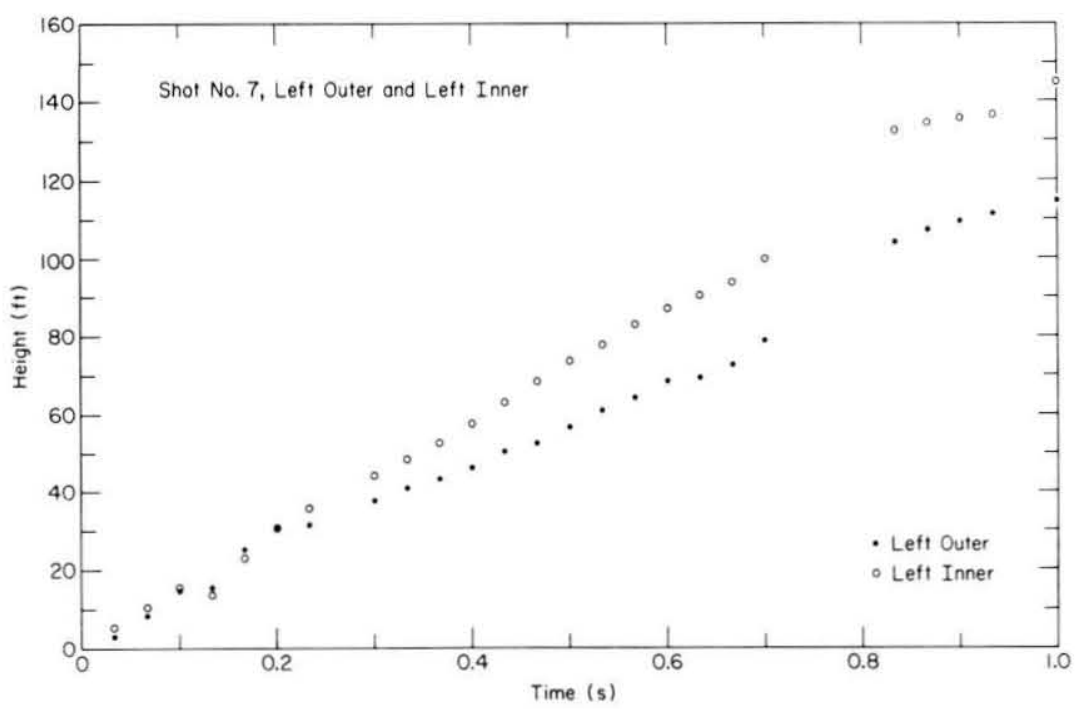

Figure B8. Data for left outer and left inner of shot no. 7.

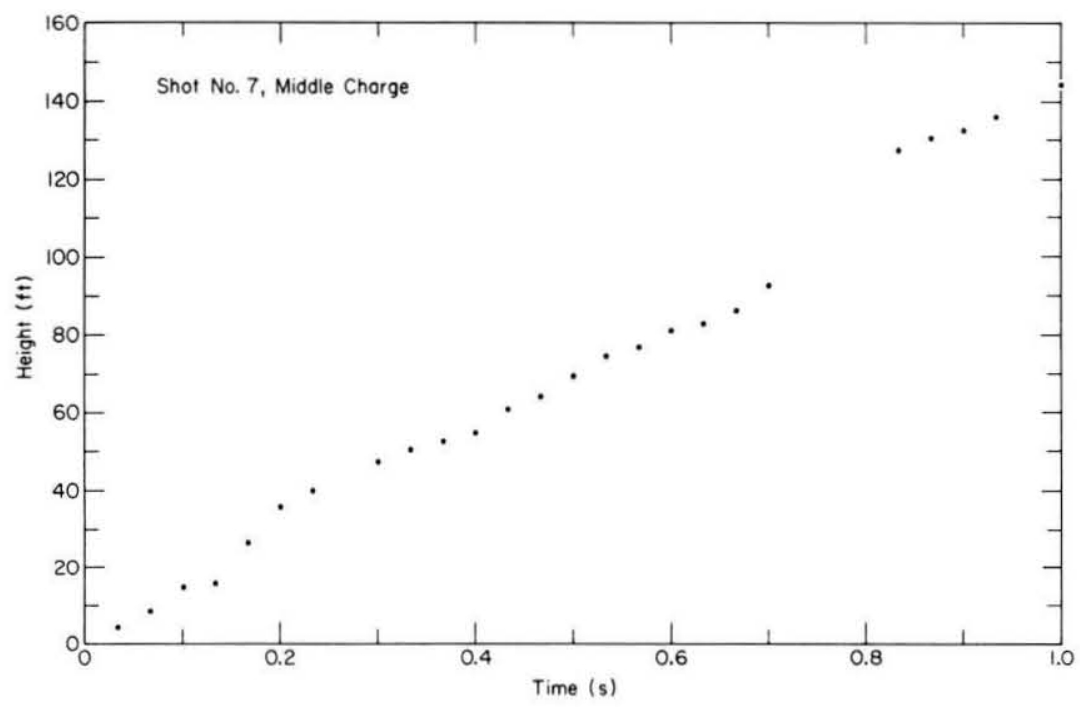

Figure B9. Data for middle charge of shot no. 7. 